TERMINUS

t. 19 (2017), z. 4 (45), s. $759-795$

doi:10.4467/20843844TE.17.020.9347

www.ejournals.eu/Terminus

Karol Łopatecki

Uniwersytet w Białymstoku

k.lopatecki@uwb.edu.pl

\title{
Ocena wiarygodności źródeł kartograficznych prezentujących oblężenie Połocka z 1579 roku'
}

\section{Abstract \\ An Assessment of the Credibility of Cartographic Sources Presenting the Siege of Polatsk in 1579}

This paper presents an analysis of cartographic works made in connection with the siege and capture of the Polatsk fortress by the army of Stephen Báthory in 1579. The aim of the study is to recompare the content of cartographic sources concerning the siege of Polatsk with the preserved plans from the middle $16^{\text {th }}$ and early $17^{\text {th }}$ centuries.

The most accurate and credible plan of Polatsk from 1579 is a print made by Stanisław Pachołowiecki. The outline of the fortifications was presented in a fine way, fundamentally consistent with a plan of the same fortress from the mid- $17^{\text {th }}$ century. In comparison, a drawing by Paweł Thurn (Czumthurn) is littered with significant mistakes. It is, therefore, most probable that the drawing was not based on the same model as the print; it might have been patterned after sketches made by an Italian engineer, Petrus Francus.

The analysis conducted indicates that the print of Georg Mack the younger cannot be treated as a cartographic source but only as its author's imagination about the events that took place at the influx of the Palata river to Daugava. It was based

1 Artykuł powstał w ramach projektu badawczego Narodowego Centrum Nauki Opus (nr 2014/15/B/HS2/01104) Związki literatury polskiej i kartografii w XVI I pot. XVII w. 
on written information and does not seem to have any foundation in plans made at Polatsk. The instance of a woodcut with the siege of the Starodub fortress that was repeated in a work of Aleksander Gwagnin as the representation of the capture of Polatsk shows that it is necessary to perform critical source analysis every single time.

In the article, the author introduced a heretofore largely unknown plan of the extension of Polatsk kept in Riksarkivet in Stockholm. It has been established that the plan was probably made in the years 1647-1654 in consequence of a fire that destroyed the castles. It depicts the former fortifications with planned bastion works marked in red. In his audacious concept, the military engineer resigned from the natural protection provided by Palata and planned to build bastion fortifications on the other bank of the river. This ring would have been the first defence line of a regular shape and was supposed to provide good defence synchronisation with the Lower Castle. A comparison of this plan with a map form 1707 shows that this concept was not realized.

Keywords: Polatsk, tactics in the $16^{\text {th }}$ century, siege operations, renaissance military cartography, Stanisław Pachołowiecki, Livonian War

Niniejszy artykuł analizuje szesnastowieczne dzieła kartograficzne przedstawiające oblężenie i zdobycie Połocka w 1579 roku przez wojska Stefana Batorego. Problematyka ta doczekała się gruntownych studiów Stanisława Alexandrowicza, który wykorzystał w swojej pracy miedzioryt Stanisława Pachołowieckiego, a także odkryty przez siebie rysunek Pawła z Thurnu (Czumthurna) oraz drzeworyt Georga Macka ${ }^{2}$. Autor ocenił, że plan Połocka z miedziorytu Pachołowieckiego jest „schematyczny, pozbawiony indywidualizacji szczegółów”. W związku z tym zdecydowanie wyżej ocenił rysunek Pawła

2 S. Alexandrowicz, Źródła kartograficzne do wyprawy połockiej Stefana Batorego roku 1579, w: Od armii komputowej do narodowej (XVI-XX w.), red. Z. Karpus, W. Rezmer, Toruń 1998, s. 28-43; S. Alexandrowicz, Kartografia Wielkiego Księstwa Litewskiego od XV do połowy XVIII wieku, Warszawa 2012, s. 174-178. Alexandrowiczowi nieznane były inne nowożytne plany Połocka. Do porównania wykorzystywał przede wszystkim dwie francuskie mapy powstałe w 1812 roku. Na ich podstawie autor wyliczyl, że skala planu była różna i waha się od $1: 18700$ do $1: 24600$. 
z Thurnu z archiwum w Dreźnie. Zauważył jedynie, że „,w jednym istotnym szczególe miedzioryt zawiera treść bogatszą niż rysunek: Zapołocie [...]. Na rysunku w miejscu tym widoczne są zgliszcza”’3. Ocena ta spowodowała, że autor przede wszystkim skupił się na analizie rysunku, a znacznie mniej miejsca poświęcił samej grafice. Celem artykułu jest ponowne skonfrontowanie treści zawartych w kartograficznych przekazach z oblężenia Połocka z istniejącymi planami miasta twierdzy z połowy XVII i początków XVIII stulecia ${ }^{4}$. Zdobycie Połocka odbiło się szerokim echem w całej Europie ${ }^{5}$. Oprócz licznych utworów literackich i poetyckich ${ }^{6}$, powstały aż cztery plastyczne przedstawienia oblężenia:

1. Miedzioryt z 1580 roku Obsidio et expugnatio munitissimae arcis Polocensis (Oblężenie i zdobycie warownej twierdzy połockiej)

3 S. Alexandrowicz, Źródła kartograficzne do wyprawy połockiej..., s. 36-37.

4 Kriegsarkivet (Stockholm), Utländska stads- och fästningsplaner, Polen, Polock 1; Библиотека Российской Академии наук. Санкт-Петербург, Рукописный отдел, Собрание иностранных рукописей, $\mathrm{F}^{\circ} 266$, т. 4, k. 48, rys. 52; Российский государственный военно-исторический архив, f. 846, ор. 16, dz. 22367. Charakterystykę źródeł kartograficznych dotyczących Połocka, przede wszystkim z lat: 1579, 1707, 1778, zaprezentowano w pracach: Г.В. Штыхов, С.В. Тарасов, Д.В. Дук, Историография и источники, w: Полоик, ред. О.Н. Левко, Минск 2012, s. 18-25; А. Белы, Plan von Polotzko anno 1707, „Спадчына” 10 (1998), 4, s. 12-15; idem, Полацк у нямецккіх “Лятучых лістках” ХVI cm. Інфляникая вайна на старонках першых еуррапейскіх газет, „Спадчына” 9 (1997), 6, s. 213219; Ю.В. Чантурия, Градостроительное искусство Беларуси второй половины XVI - первой половины XIX в., Минск 2005, s. 272-278.

5 K. Zawadzki, Akcja prasowa Stefana Batorego w czasie wypraw moskiewskich 1579-1581, w: Dzieje polskiej kartografii wojskowej i myśli strategicznej. Materiały $z$ konferencji, oprac. В. Krassowski, J. Madej, Warszawa 1982, s. 121-122; А.И. ФИлюшкин, Завоевание Стефаном Баторием Полоцка в 1579 г. в европейском нарративе, „Вестник Санкт-Петербургского университета. Серия 2. История” 1 (2014), s. 5-9.

6 Zob. J. Niedźwiedź, Atlas Księstwa Połockiego Stanisława Pachołowieckiego (1580): propaganda, genologia i tworzenie wiedzy geograficznej, „Terminus” 19 (2017), z. 1 (42), s. 131-132; idem, Polska szesnastowieczna propaganda wojenna $w$ działaniu: przypadek Atlasu Księstwa Połockiego (1580), „Terminus” 19 (2017), z. 3 (44), s. $477-510$. 
wydany przez Giovanniego Battistę Cavalieriego w Rzymie na podstawie rysunku Stanisława Pachołowieckiego ${ }^{7}$ (il. 1).

2. Rysunek przedstawiający zdobycie Połocka autorstwa Pawła z Thurnu (Czumthurn, Zumthorn) ${ }^{8}$. Był to działający w Krakowie malarz, czynny w latach 1573-1598'. Stanisław Alexandrowicz uważał, że wykonał on rysunek na podstawie rękopiśmiennego planu Stanisława Pachołowieckiego. $Z$ tego powodu ten zasłużony badacz oznacza podwójne autorstwo rysunku: Pachołowiecki-Zumthorn ${ }^{10}$ (il. 2).

7 Wymiary ryciny to: $39,5 \mathrm{~cm}$ x $26,4 \mathrm{~cm}$. Opracowanie krytyczne nazw odnotowanych na mapie: G. Franczak, Atlas Księstwa Połockiego Stanisława Pachołowieckiego z 1580 roku - transkrypcja i przekład, „Terminus” 19 (2017), z. 1 (42), s. 61-74. Zob. K. Kozica, Charakterystyka prac kartograficznych Stanisława Pachołowieckiego (1580), „Terminus” 19 (2017), z. 1 (42), s. 43-46.

8 Staatsarchiv Dresden, sygn. R. Schrank VII, Fach 90, nr 17a. Wymiary rysunku $31,8 \mathrm{~cm} \times 38,8 \mathrm{~cm}$ (ilustracja bez ramki $30 \mathrm{~cm} \times 37 \mathrm{~cm}$ ). Kolorowa reprodukcja: S. Alexandrowicz, Dziedzictwo kartografii wojskowej ziem Wielkiego Księstwa Litewskiego. Jej funkcje źródłowe i praktyczne na tle kartografii krajów Europy Wschodniej XVI i XVII wieku, w: Środowisko kulturotwórcze i kontakty kulturalne na tle Wielkiego Księstwa Litewskiego od XV do XIX wieku, red. W. Augustyniak, Warszawa 2009, wkładka na końcu tomu.

9 Zob. S. Alexandrowicz, Kartografia wojskowa Wielkiego Księstwa Litewskiego do połowy XVII wieku, w: Kartografia wojskowa krajów strefy bałtyckiej XVI-XX w. Materiały konferencji naukowej, Toruń, 20-22 października 1994 r., red. S. Alexandrowicz, Z. Karpus, W. Rezmer, Toruń 1996, s. 14; E. Rastawiecki, Słownik malarzów polskich, tudzież obcych $w$ Polsce osiadłych lub czasowo $w$ niej przebywajacych, t. 2, Warszawa 1851, s. 90-91; Ch. Rohrschneider, Czumturn (Czum Thurn; Czumstur; Czumthorn; Tomtorn; Tomturn), Paweł (Paul), w: Allgemeines Künstlerlexikon. Die bildenden Künstler aller Zeiten und Völker, Bd. 23, München 1999, s. 319. Przez pewien okres przyjmowano, że jest to oryginalny rysunek wykonany w 1579 roku przez Stanisława Pachołowieckiego (zob. S. Alexandrowicz, Nowe źródło ikonograficzne do oblężenia Połocka w 1579 r., „Kwartalnik Historii Kultury Materialnej” 19 (1971), nr 1, s. 3-29). Uważna analiza oryginału wykazała, że zawiera on podpis: „PAVEL TOMTORN PICTOR GRAFE” (zob. F. Bönisch, H. Brichzin, K. Schillinger, W. Stams, Kursächsische Kartographie bis zum Dreissigjährigen Krieg, Bd. 1: Die Anfänge des Kartenwesens Gebundene Ausgabe, Berlin 1990, s. 186-187).

${ }_{10}$ Zob. S. Alexandrowicz, Źródła kartograficzne do wyprawy połockiej..., s. 34-35: „Niewątpliwie materiałem wyjściowym [rysunku Pawła z Thurnu - K.Ł.] 


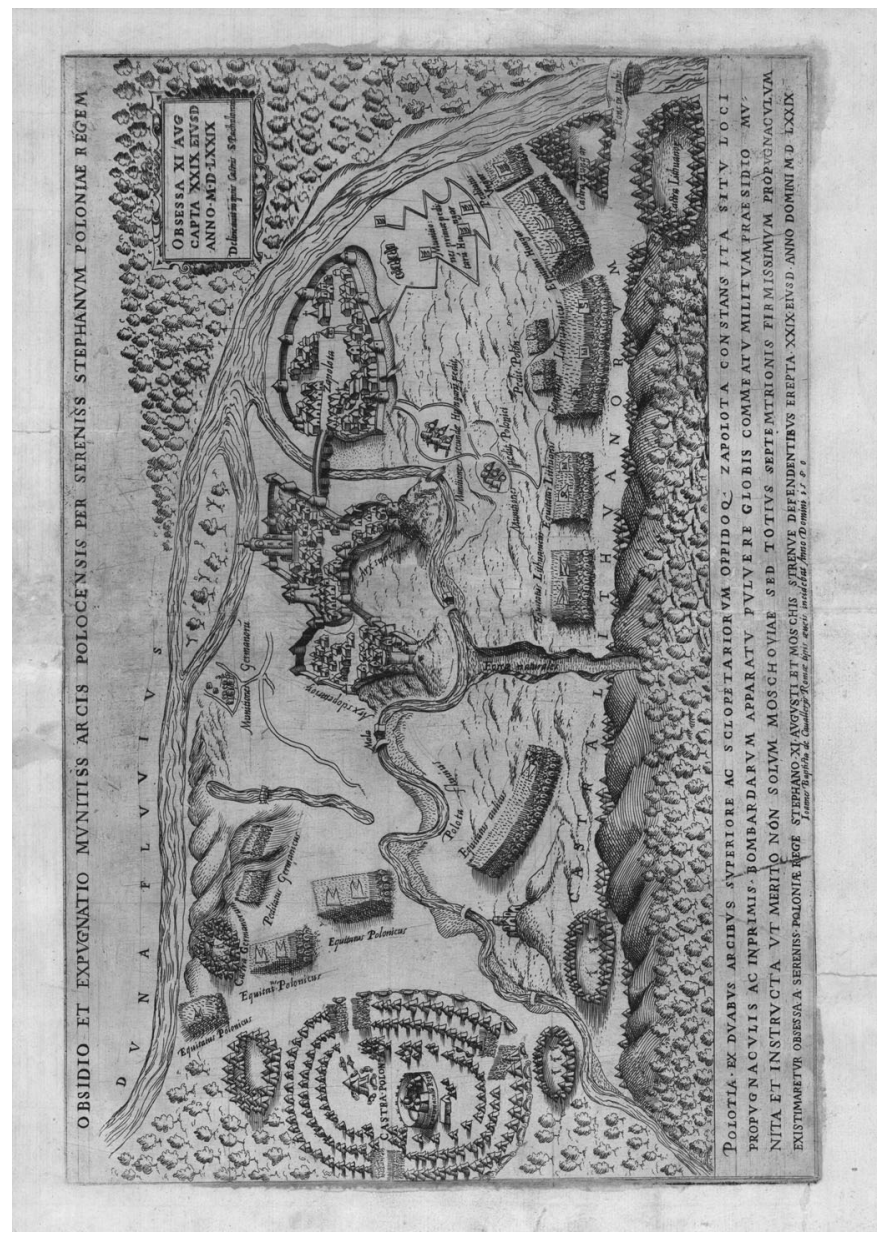

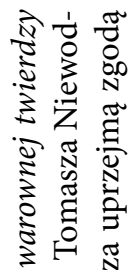

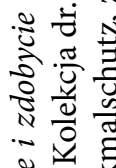

: )

览

○

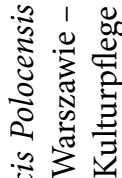

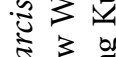

急需焉

娄步

:

ई

율 곤

50

눈ㄷำ

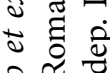

$\therefore$ 둥

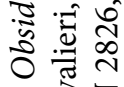

氞穾 Z

.

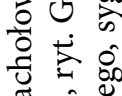

คิ

म $\frac{\pi}{\widetilde{\pi}}$

픈. 


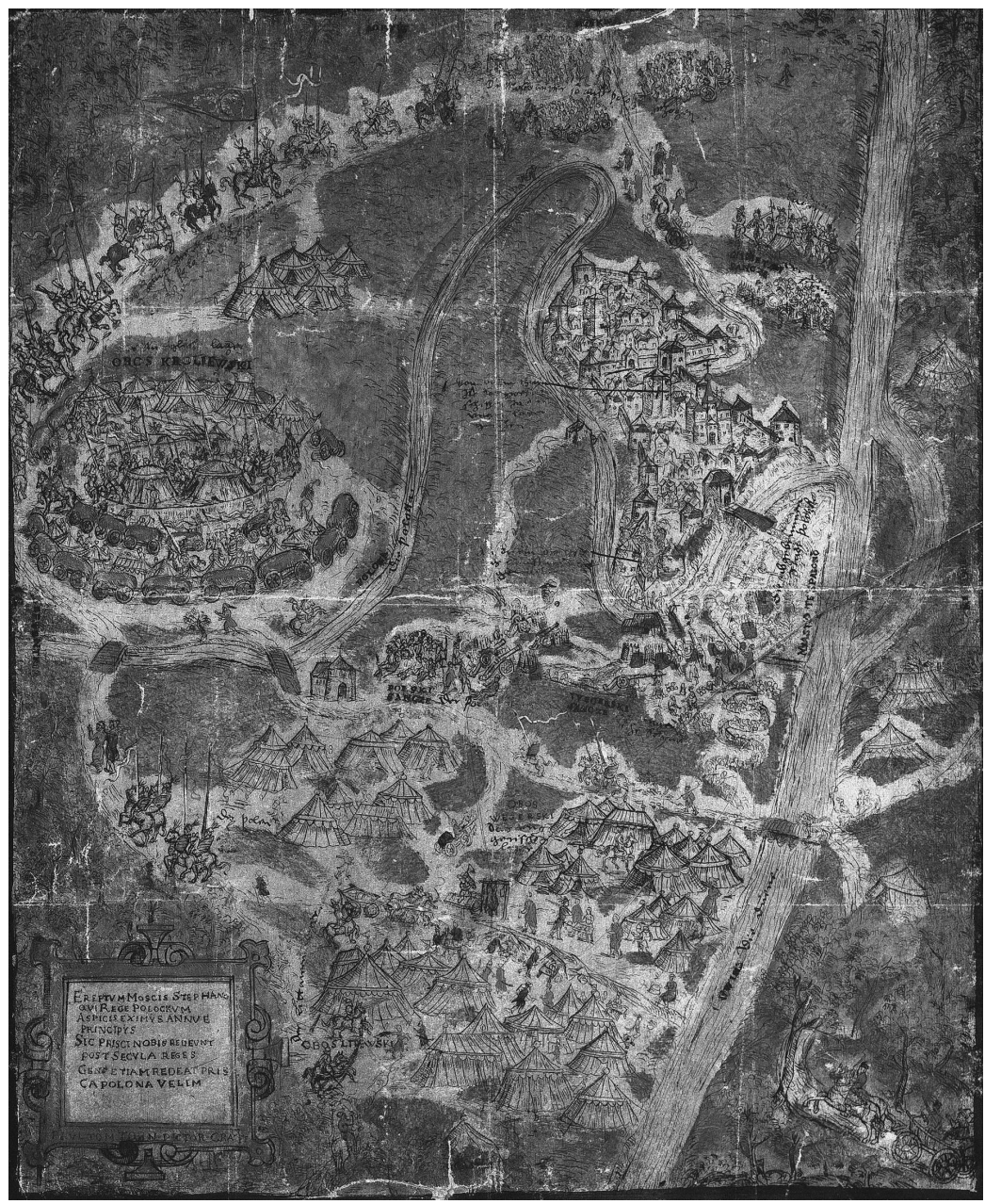

Il. 2. Rysunek przedstawiający zdobycie Połocka autorstwa Pawła z Thurnu (Staatsarchiv Dresden, sygn. R. Schrank VII, Fach 90, nr 17a) 
3. Kolorowany drzeworyt wykonany przez Georga Macka starszego, umieszczony w ulotnej gazetce wydanej w Norymberdze w 1579 roku $^{11}$. Widok ten ma charakter wtórny. Ilustracja została przypuszczalnie stworzona na podstawie wydanego wraz $\mathrm{z}$ grafiką tekstu relacjonującego zdobycie twierdzy ${ }^{12}$. Topografia zamku strzeleckiego jest fantazyjna, a zamek górny ${ }^{13}$ sprawia wrażenie obszernego, obwarowanego miasta zbudowanego na planie kwadratu i ulokowanego w widłach rzek Dźwiny i Połoty. Ponadto niepoprawnie został przedstawiony kierunek i ujście rzeki Połoty, nietrafne jest też ulokowanie w Zapoło-

były, wykonane podczas oblężenia Połocka lub zaraz po jego zdobyciu, rysunki Stanisława Pachołowieckiego". Rysunek wykonany w Krakowie to niejedyny przykład przenikania się kartografii i malarstwa. Tematyka militarna związana z rokiem 1579 musiała stać się tematem obrazów batalistycznych zamawianych przez magnaterię. Znamy aż cztery inne wyobrażenia dotyczące wydarzeń 1579 roku, wszystkie namalowane z polecenia Krzysztofa Radziwiłła: wyprawa Krzysztofa Radziwiłła przez Dorpat aż pod Psków; zdobycie Sitna i Kozian; zwycięska bitwa pod Sokołem; zniszczenie twierdzy Sokół. Muzeum Wojska Polskiego w Warszawie, nr inw. $16594 \mathrm{~A}^{\star}, 16595 \mathrm{~A}^{\star}, 16596 \mathrm{~A}^{*}, 16597 \mathrm{~A}^{\star}$.

11 Warhaffte Contrafactur vnd gewisse Zeitung, welcher massen die Königliche Wirden in Poln, die Stat und daß Schloß Polotzko in Littawen gelegen, sampt andern Heusern, die der Moscowiter vor der zeyt der Korn unbillich abgedrungen, widerumben belegert und eingenommen. Auch was sich in solchem Zug verloffen hat, Nürnberg: Georg Mack, [1579], [s. 1]. Został on odkryty i opisany w pracy: J. Pirożyński, $Z$ dziejów obiegu informacji w Europie XVI wieku. Nowiny z Polski $w$ kolekcji Jana Jakuba Wicka w Zurychu z lat 1560-1587, Kraków 1995 (Zeszyty Naukowe Uniwersytetu Jagiellońskiego. Prace Historyczne 115), s. 295 (il. 22). W historiografii białoruskiej: А. Белы, Полаик..., s. 213-219. Zob. E. Weller, Die ersten deutschen Zeitungen mit einer Bibliographie (1505-1599), Hildesheim-Zürich-New York 1994, s. 178 , poz. 268 (z błędną datą 1564$)$.

12 Odmiennie sądzi: S. Alexandrowicz, Źródła kartograficzne do wyprawy połockiej..., s. 42-43, który przydaje mu wartość dokumentacyjną.

${ }_{13} \mathrm{~W}$ pracy przyjmuję nazewnictwo zaproponowane przez Grzegorza Franczaka w tłumaczeniu inskrypcji znajdujących się na mapach i planach wchodzących w skład Atlasu Księstwa Połockiego Stanisława Pachołowieckiego w artykule w pierwszym z trzech zeszytów „Terminusa” poświęconych Atlasowi. G. Franczak, Atlas Księstwa Połockiego Stanisława Pachołowieckiego z 1580 roku - transkrypcja i przekład, „Terminus” 19 (2017), z. 1 (42), s. 61-74. 
ciu potężnej wieży (której nie było), błędnie oznaczono most przerzucony przez Połotę oraz nie zaznaczono wyspy na Dźwinie. Nie można uznać tego zabytku za źródło kartograficzne, natomiast w warstwie ikonograficznej jest to obiekt istotny dla badaczy między innymi uzbrojenia i artylerii. Podkreślić należy również przekaz propagandowy - ukazano okrucieństwo Rosjan bestialsko torturujących złapanych żołnierzy (scena w zamku strzeleckim) oraz ceremonię podziękowania Rosjan za łaskawe przyjęcie warunków kapitulacji przez Stefana Batorego ${ }^{14}$ (il. 3).

4. Rycina umieszczona w pracy Aleksandra Gwagnina z 1611 roku przedstawiająca podpalenie Połocka ${ }^{15}$ (il. 4). Drzeworyt ten w rzeczywistości prezentuje wydarzenia nie z 1579 roku, lecz ze zdobycia zamku Starodub przez Jana Tarnowskiego w $1535 \mathrm{roku}^{16}$. Na ilustracji wódz ten znajduje się na pierwszym planie, przed namiotem udekorowanym herbem Tarnowskich Leliwa. Drzeworyt został wykonany na potrzeby wcześniejszej Kroniki Marcina Bielskiego i po raz pierwszy odbity w edycji z 1564 roku, a następnie przedrukowany w wersji Kroniki Joachima Bielskiego z 1597 roku $^{17}$.

14 S. Alexandrowicz, Źródła kartograficzne do wyprawy połockiej..., s. 41.

15 A. Gwagnin, Kronika Sarmacyjej Europskiej, Kraków: Mikołaj Lob, 1611, s. 208.

16 А.И. Филюшкин, Завоевание Стефаном Баторием Полоцка..., s. 9. Nie oznacza to jednak, że rycinę tę można wykorzystywać przy analizie zamku Starodub. Na rycinie mamy do czynienia z twierdzą zbudowaną z kamienia i cegły, gdy w rzeczywistości był to typowy zamek drewniano-ziemny.

${ }_{17}$ M. Bielski, Kronika to jest historyja świata [...], Kraków: Mateusz Siebeneicher, 1564, k. 423. Egzemplarz zdygitalizowany: http://mbc.malopolska.pl/dlibra/ doccontent?id=82767 (dostęp: 14.12.2016). Było to trzecie wydanie książki, pierwsze ukazały się w latach 1551, 1554. D. Śnieżko, Swojskie i obce w kronice uniwersalnej (przykład Marcina Bielskiego), „Teksty Drugie. Teoria literatury, krytyka, interpretacja” (2003), nr 1, s. 23-24. Edycja przygotowana przez Joachima Bielskiego: M. Bielski, Kronika polska, wyd. J. Bielski, Kraków: Jakub Siebeneicher, 1597, s. 574. O ile większość grafik z 1564 roku sygnowana jest monogramem I.B., o tyle nie odnajduję takiej informacji na ilustracji przedstawiającej zdobycie Starodubu. Por. M. Gębarowicz, Początki malarstwa historycznego w Polsce, Wrocław 1981, s. 13; E. Chojecka, Drzeworyty Kroniki Joachima Bielskiego i zaginione gobeliny Anny Jagiellonki. Ze studiów 


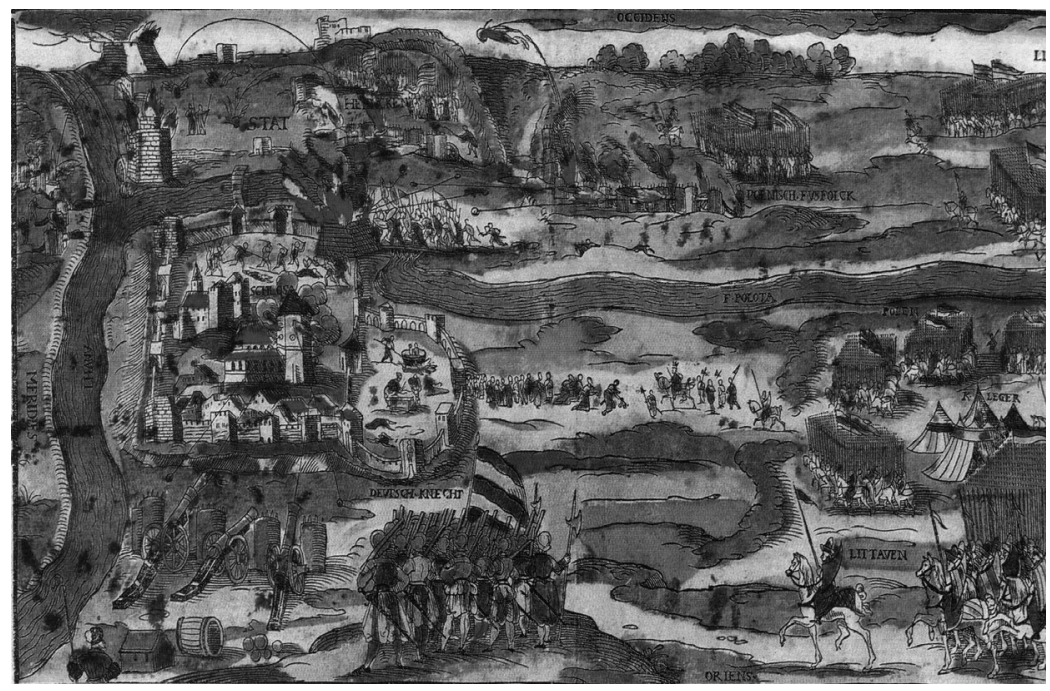

Il. 3. Kolorowany drzeworyt Georga Macka st. umieszczony w ulotnej gazetce, Die Eroberung von Polotsk in Litauen, Nürnberg 1579 (Biblioteka Książąt Czartoryskich, sygn. XV-R. 6813)

W tłumaczeniu pracy Gwagnina umieszczono ryciny zaczerpnięte z wcześniejszych prac i przyporządkowano je wtórnie do przedstawianych wydarzeń. Ilustracje te miały przede wszystkim walor retoryczny, nie dokumentacyjny ${ }^{18}$. W zasadzie grafiki tej nie należałoby brać pod uwagę. Część badaczy traktuje ją jednak jako wiarygodne źródło informacji o zdobyciu Połocka w 1579 roku ${ }^{19}$. Niektórzy posuwają się

nad zwiąkami artystycznymi Krakowa i Brzegu w XVI wieku, „Rocznik Sztuki Śląskiej" 7 (1970), s. 39-40. W kronice Gwagnina część z drzeworytów o tematyce historycznej została skopiowana z zupełnie innych dzieł. Przykładowo dwie ilustracje z Historii o Skandenbergu Macedonie zostały powtórzone z prac upamiętniających 12 wielkich czynów Karola V. Zob. M. Morka, [recenzja książki:] T. Jakimowicz, Temat historyczny w sztuce ostatnich Jagiellonów, „Biuletyn Historii Sztuki” 49 (1987), 3-4, s. 352-353, 357. Analiza treści zawartej na rycinie prezentującej zdobycie twierdzy Starodub wskazuje na oryginalne cechy dzieła.

18 M. Morka, [recenzja książki:] T. Jakimowicz, s. 358.

19 У. Арлоў, 3. Герасімовіч, Ілюстраваная гісторыя: краіна Беларусь, Bratislava 2003, s. 158. 


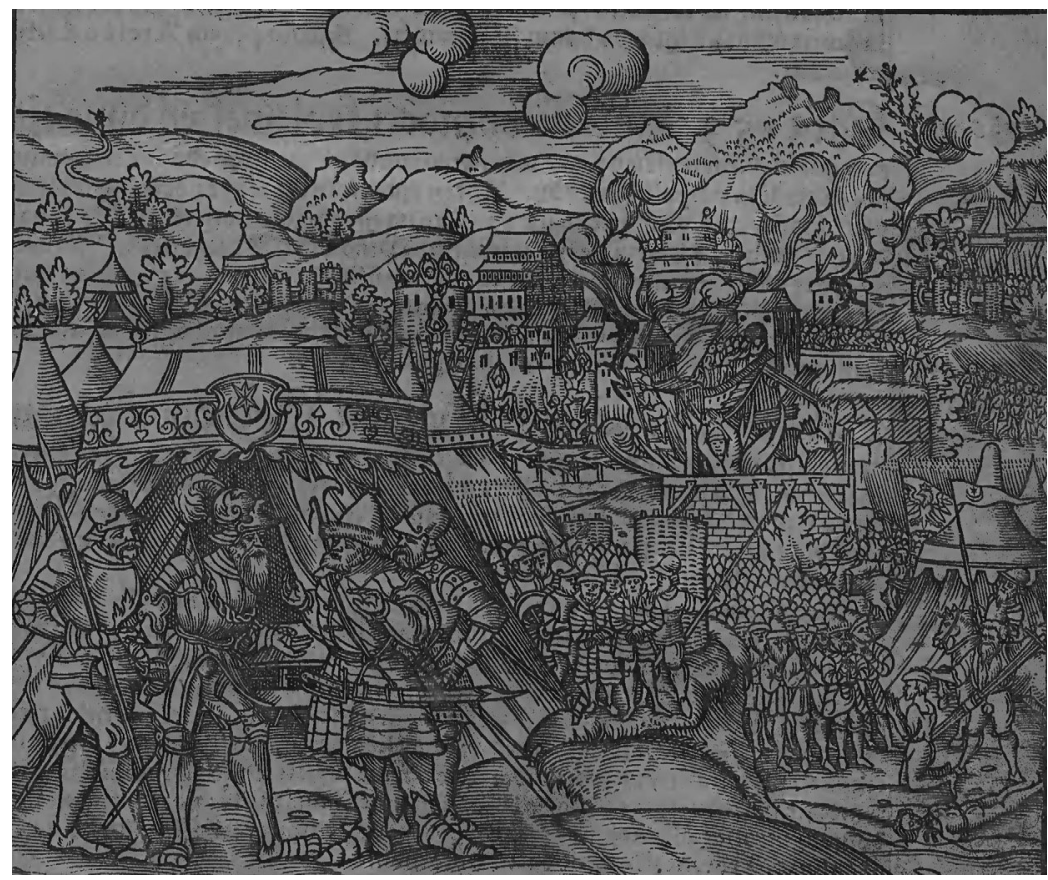

Il. 4. Rycina w pracy Aleksandra Gwagnina, Kronika Sarmacyjej Europskiej, Kraków: Mikołaj Lob, 1611, s. 208

znacznie dalej i starają się wyciągać pogłębione wnioski na podstawie tego źródła, na przykład U. Ciależnikau i A. Patuszkin (il. 5) ${ }^{20}$.

Nadal otwarta pozostaje kwestia, który z wizerunków oblężenia pierwszy czy też drugi - jest planem najlepiej oddającym rzeczywistość. Oba są źródłami pośrednimi wykonanymi na podstawie rysunku sporządzonego w obozie wojskowym w sierpniu 1579 roku. Według

20 У.І. Цялежнікаў, А.М. Латушкін, Умацаванні 2-ц̆ паловы XVI cm. паміж Верхнім і Ніжнім замкамі у Полаику, „Пытанні мастацтвазнаўства, этналогіi і фалькларыстыкі” 17 (2014), s. 58-66. 


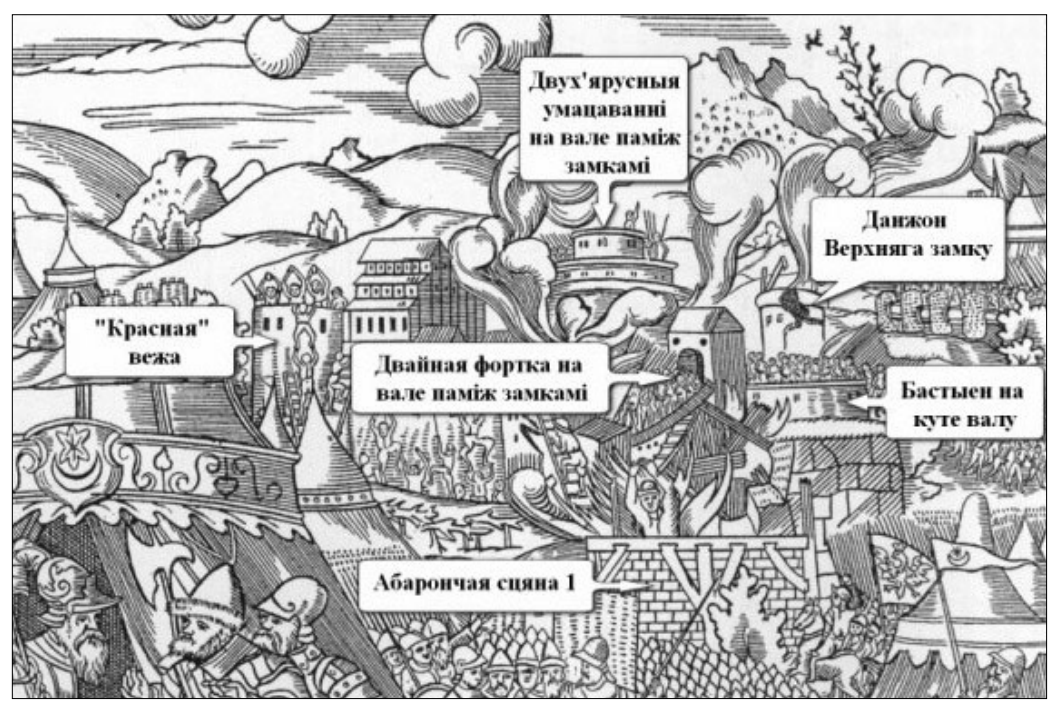

Il. 5. Przeprowadzana przez badaczy analiza fortyfikacji Połocka w świetle ryciny dokumentującej zdobycie Starodubu (У.І. Цялежнікаў, А.М. Латушкін, Умацаванні 2-ц̌ паловы XVI cm. паміж Верхнім і Ніжнім замкамі y Полацку, „Пытанні мастацтвазнаўства, этналогіi і фалькларыстыкі” 17 (2014), s. 61)

Stanisława Alexandrowicza rysunek Pawła z Thurnu jest zdecydowanie bardziej wiarygodny, co autor ocenia na podstawie zestawienia obu przedstawień z wykonanymi w latach 1707 i 1812 planami Połocka ${ }^{21}$.

W pierwszej kolejności należy przyjrzeć się istotnym różnicom pomiędzy źródłem nr 1 a źródłem nr 2 (il. 6). Nie biorę tu pod uwagę przedstawień postaci, zmienionej orientacji i innych elementów o charakterze kompozycyjnym ${ }^{22}$. Obiekt przedstawiony na obu źródłach

21 S. Alexandrowicz, Kartografia Wielkiego Księstwa Litewskiego..., s. 176, przypis 371; idem, Dziedzictwo kartografii, s. 199-200; idem, Źródła kartograficzne do wyprawy połockiej..., s. 30-31, 35, 42-43.

22 Por. S. Alexandrowicz, Nowe źródło..., s. 4-5. 


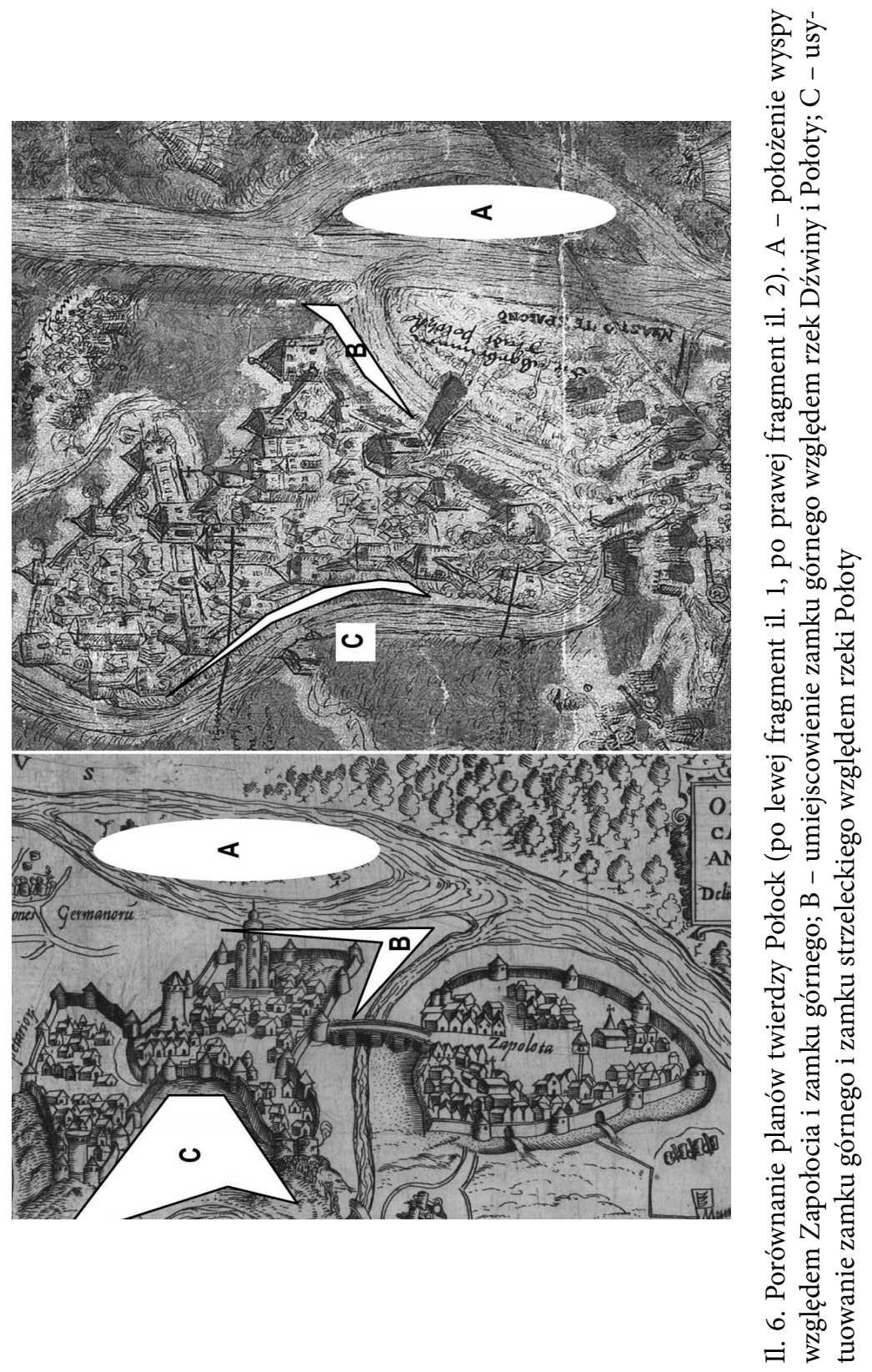


jest zbliżony, lecz nie identyczny, a odmienności występują w trzech zasadniczych kwestiach. Pierwsza to lokalizacja wyspy na rzece Dźwinie (il. 6, lit. A). Na miedziorycie jest ona zaznaczona na wysokości zamków górnego i strzeleckiego, na rysunku zaś znajduje się naprzeciw zniszczonego Zapołocia. Druga różnica dotyczy umiejscowienia zamku górnego w stosunku do Dźwiny (il. 6, lit. B). U Pawła z Thurnu obiekt ten nie przylega do Dźwiny, a jedynie jest dopasowany do biegu Połoty. Zupełnie inaczej u Pachołowieckiego, u którego jeden bok zamku jest zbieżny z ukształtowaniem brzegu Dźwiny. Po trzecie, bieg rzeki Połoty na odcinku pomiędzy zamkami znacznie się różni - na rysunku ściśle przylega on do skarpy i fortyfikacji, na miedziorycie zaś znajduje się znaczna przestrzeń tworząca trójkątne pole (il. 6, lit. C). Wszystkie te różnice z punktu widzenia kartografii wojskowej mają kluczowe znaczenie, w szczególności podczas wykorzystywania planów w działaniach oblężniczych.

Nie można się zgodzić z prof. Stanisławem Alexandrowiczem, który uznał wyższość rysunku nad miedziorytem (il. 7) ${ }^{23}$. Warto jednak wykorzystać metodologię zaproponowaną przez tego badacza, który zestawił oba źródła z mapą wykonaną na potrzeby wojskowe w roku 1812, w późniejszych pracach uzupełnił analizę również o plan z roku 1707.

Wykorzystany do porównania przez autora plan z 1707 roku (mimo że założenie obronne jest już bardzo przekształcone) nie jest jednoznaczny. Źródło to wskazuje między innymi na to, że wyspa położona jest na wysokości obu zamków (na miedziorycie pkt. 8 i 9), nie zaś przy dawnym mieście Zapołota (pkt. 7) ${ }^{24}$. Pozostałe elementy, wobec daleko posuniętych przekształceń trudno ocenić.

23 S. Alexandrowicz, Kartografia Wielkiego Księstwa Litewskiego..., s. 176, przypis 371: „Z rzeczywistym ukształtowaniem terenu wokół Połocka, w szczególności zaś z biegiem rzeki Dźwiny, plan rękopiśmienny zgadza się znacznie lepiej niż sztych. Wystarczy porównać go z planem Połocka, pochodzącym z XVIII w., [...] czy lepiej oddającym topografię okolic miasta planem z roku 1707”. Na przywołanych mapach widzimy jedynie niewielki fragment biegu Dźwiny, znacznie mniejszy niż na grafice. Por. idem, Źródła kartograficzne do wyprawy połockiej..., s. 30-31.

24 Библиотека Российской Академии наук. Санкт-Петербург, Рукописный отдел, Собрание иностранных рукописей, $\mathrm{F}^{\circ} 266$, t. 4, k. 48, rys. 52; Российский 
Warto nadmienić, że bieg rzeki Połoty odzwierciedlony na planie z 1707 roku sugeruje właściwą lokalizację głównego obozu na sztychu, a nie na rysunku. Obóz królewski był umiejscowiony na granicy późniejszego miasta (pkt. 3), pomiędzy Połotą a Dźwiną, a dzięki lokalizacji mniejszych obozów (m.in. piechoty niemieckiej) oba zamki zostały odcięte w przestrzeni powstałej pomiędzy rzekami a twierdzą. Potwierdza tę hipotezę relacja Antonia Martinelliego, który pisze, że obóz królewski znajdował się przy „rowie”, tak jak obóz i szaniec niemiecki (il. 1) ${ }^{25}$. Ów rów, czy też pozostałość po fosie lub przekopie, mógł również zostać nazwany jeziorem, stawem. Tak też odnotowano: „Za Połotą i jakiemś jeziorem, stał obóz królewski” („Ultra Polottam inter flumen et lacum quendam, quemadmodum ostendimus, regia castra erant”) ${ }^{26}$. Na miedziorycie (il. 1) przekop ten, czy jak chcą kronikarze jezioro, jest wyraźnie zaznaczony wraz $\mathrm{z}$ przerzuconym nad jego brzegami mostem, co notabene świadczy o tym, że mamy do czynienia ze zbiornikiem wodnym, a nie wykopanym zwykłym rowem lub suchą fosą. Podobnego elementu topograficznego na rysunku brak. Ów rów widoczny jest natomiast na planach wykonanych w 1707 roku. Na jego wysokości kończy się założenie obronne miasta od wschodu (il. 7). Na tej wysokości rzeka

государственный военно-исторический архив, f. 846, op. 16, dz. 22367. Pomiędzy planami występują różnice, mapa kolorowana powstała 18 stycznia, kolejne źródło jest już z końca roku, gdyż bardziej rozbudowane są założenia bastionowe. Por. А. Белы, Plan von Polotzko..., s. 13.

25 А. Мартинелли, История взятия Полоцка польским королем Стефаном Баторием в 1579 году, подготовка текста и перевод И.В. Дубровского, w: Русский Сборник. Исследования по истории России, т. 21, ред. О.Р. Айрапетов et al., Москва 2017, s. 45-46, 48.

26 R. Heidenstein, Dzieje Polski od śmierci Zygmunta Augusta do roku 1594. Ksiąg XII, t. 1, przeł. M. Gliszczyński, Petersburg 1857, s. 314; R. Heidenstein, Pamiętniki wojny moskiewskiej w 6 księgach, przeł. i wyd. J. Czubek, Lwów 1894, s. 56: „Za Połotą przestrzeń między tą rzeką a jekiemś jeziorem zajmował, jak to powiedzieliśmy obóz królewski”. W oryginale: R. Heidenstein, De bello Moscovitico Commentariorum, lib. sex, Kraków: Drukarnia Łazarzowa, 1584, s. 54. 


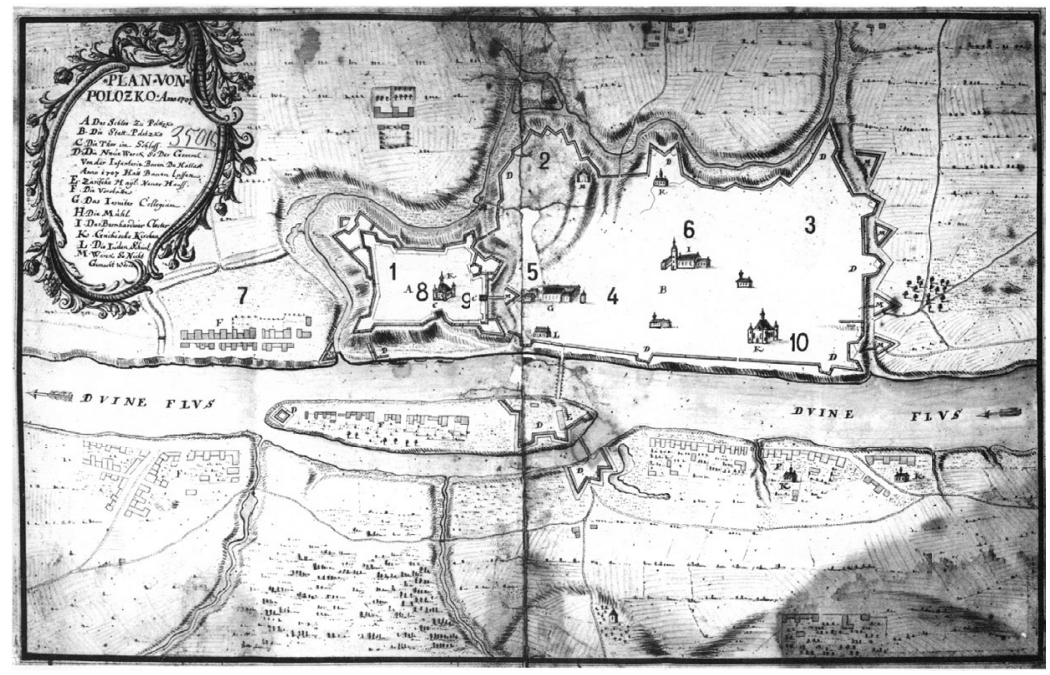

Il. 7. Plan Połocka z 1707 roku, mapa powstała prawdopodobnie w latach 20 . XVIII wieku; numeracja wtórnie dodana (Российский государственный военно-исторический архив, f. 846, ор. 16, dz. 22367, reprodukcja za: Чантурия Ю.В., Градостроительное искусство Беларуси второй половины XVI - первой половины ХІХ в., Минск 2005, s. 273) 27

Połota skręca na północ, co widoczne jest również na sztychu (tam skręca na północny-wschód).

Istnieje jednak dużo lepsze źródło kartograficzne, które powinno rozwiać wszelkie wątpliwości. Jest to plan zatytułowany Die Stadt Po-

27 Reprodukcja z naniesionymi numerami znajduje się także w: Г.В. Штыхов, С.В. Тарасов, Д.В. Дук, Историография и источники, s. 23; Р.М. Платонов, М.А. Платонов, А.С. Давидович, Градостроительство Полоика в XIV-XVIII века, „Вестник Полоцкого государственного университета. Сер. F, Прикладные науки. Строительство. Прикладные науки: научно-теоретический журнал” 12 (2009), s. 11; Я.Д. Филиппенко, Исторический и композиционный анализ градообразующей роли иентральной площзади Полоцка XVI-XIX веков, „Вестник Полоцкого государственного университета. Серия F, Строительство. Прикладные науки: научно-теоретический журнал” 6 (2009), s. 16. 
loctzko, który stanowi projekt rozbudowy fortyfikacji Połocka wykonany w połowie XVII stulecia (il. 8) ${ }^{28}$. Na planie zaznaczono już ufortyfikowane miasto Połock (Die Stadt Poloctzko) ${ }^{29}$. Prace miernicze zostały więc przeprowadzone po zniszczeniu dotychczasowej zabudowy przez Rosjan w 1633 roku $^{30}$. Po tym wydarzeniu nastąpił dynamiczny proces odbudowy Wielkiego Posadu - ulokowanego pomiędzy dwoma zamkami, ograniczonymi dodatkowo rzekami Dźwiną i Połotą. Oznacza to, że plan powstał po 1638 roku, kiedy to mieszczanie zaczęli wznosić nowy parkan wokół miasta ${ }^{31}$.

Powstanie planu należy wiązać z konstytucją sejmową 1647 roku, w której zapisano, że „zamek połocki, który w niedawnych czasiech z dopuszczenia Bożego do gruntu zgorzał” zostanie w przyszłości przez króla ufortyfikowany, o czym będzie zdana relacja przed sejmem $^{32}$. Dwa lata później w uchwałach podatkowych odnotowano, że „względem restauracyi zamku połockiego, przez ogień zniszczonego" podatek czopowy z całego województwa połockiego zostanie przekazany na potrzeby jego odbudowy. W 1652 roku kolejna uchwała sejmowa podkreślała, że zamek jest nie tylko zniszczony przez pożar, ale i przez „nieprzyjaciela funditus zrujnowany”. Zo-

28 Kriegsarkivet (Stockholm), Utländska stads- och fästningsplaner, Polen, Polock 1.

29 Charakterystyka tzw. Wielkiego Posadu zob. Д.У. Дук, Полачк і палачане (IX-XVIII стст.), Наваполацк 2010, s. 78-89.

30 Археографический сборник документов, относящихся к истории Северо-3ападной Руси, т. 1, Вильно 1867, s. 271-276 (szereg dokumentów dotyczących spalenia miasta oraz nakazów ponownego osiedlenia się w mieście).

31 Постановление полоцких мещан о постройке городского тына, 21 VI 1638, w: Археографический сборник документов..., т. 1, s. 308; Д.В. Дук, Исследование оборонительных сооружений. Материалы городской застройки, w: Полоцк..., s. 314.

32 Volumina legum, t. 4, wyd. J. Ohryzko, Petersburg 1860, s. 67. Wcześniejsze konstytucje dotyczące zamku połockiego były wydawane w latach 1607, 1626 i 1638: Volumina legum, t. 2, wyd. J. Ohryzko, Petersburg 1859, s. 435; Volumina legum, t. 3 , wyd. J. Ohryzko, Petersburg 1860, s. 240, 458; por. H. Wisner, Wojsko litewskie 1 połowy XVII wieku. Cz. II, „Studia i Materiały do Historii Wojskowości” 20 (1976), s. 22. 
bowiązano wówczas wyznaczonych urzędników do wymierzenia placów w zamku górnym, które następnie powinny być rozdzielone pomiędzy obywateli województwa ${ }^{33}$. Warto podkreślić, że w ten sposób chciano narzucić obowiązek obrony zamku samej szlachcie, na co sejmik województwa połockiego wyraził zgodę (doraźnie) w przeszłości, 28 czerwca 1633 roku $^{34}$. 27 czerwca 1654 roku wojska rosyjskie po kilkugodzinnym oblężeniu zajęły miasto ${ }^{35}$. Na początku okupacji rosyjskiej wojewoda Szeremietiew opisał połockie fortyfikacje. Na terenie zamku górnego wymieniono 10 baszt i dwie bramy. Część z nich była nowymi konstrukcjami, co oznacza, że prace remontowe i budowlane przed atakiem rosyjskim trwały. Car Aleksy Michajłowicz rozkazał mieszczanom podjęcie prac fortyfikacyjnych w obrębie miasta i Zapołocia ${ }^{36}$.

Po okupacji moskiewskiej powtórnie kwestią ufortyfikowania Połocka zajął się sejm w roku 1667. Ponownie postanowiono wymierzyć place szlachcie, tym razem zarówno w zamku górnym, jak i dolnym (strzeleckim), z obowiązkiem wystawienia gospodarzy (strzelców) ${ }^{37}$. Ponadto w celu odbudowy miasta, aby „z popielisk swoich powstawało", zostało ono zwolnione z podatków na cztery lata $^{38}$. W tym czasie musiała nastąpić odbudowa założenia, gdyż

33 Volumina legum, t. 4, s. 150, 175.

34 B. Dybaś, Fortece Rzeczypospolitej. Studium z dziejów budowy fortyfikacji stałych $w$ państwie polsko-litewskim w XVII wieku, Toruń 1998, s. 311-312. Było to rozwiązanie stosowane z powodzeniem na Smoleńszczyźnie. Zob. K. Łopatecki, Organizacja, prawo i dyscyplina w polskim i litewskim pospolitym ruszeniu (do połowy XVII wieku), Białystok 2013, s. 412-432.

35 K. Bobiatyński, Od Smoleńska do Wilna. Wojna Rzeczypospolitej z Moskwa 1654-1655, Zabrze 2004, s. 40.

36 Д.В. Дук, Исследование оборонительных сооружений.., s. 310, 314.

37 Częściowo potwierdza faktyczną realizację postanowień sejmowych (zabudowa placów na terenie zamków) - odnalezione w wyniku prac archeologicznych na terenie zamku górnego kafli z herbami szlacheckimi. Д. Дук, Матэрыялы да геральдьчнай карть месцазнаходжання дварой полацкай иляхть XVIXVII cm., „Герольд Litherland” 2 (2002), 3-4, s. 84-89.

38 Volumina legum, t. 4, s. 471. 


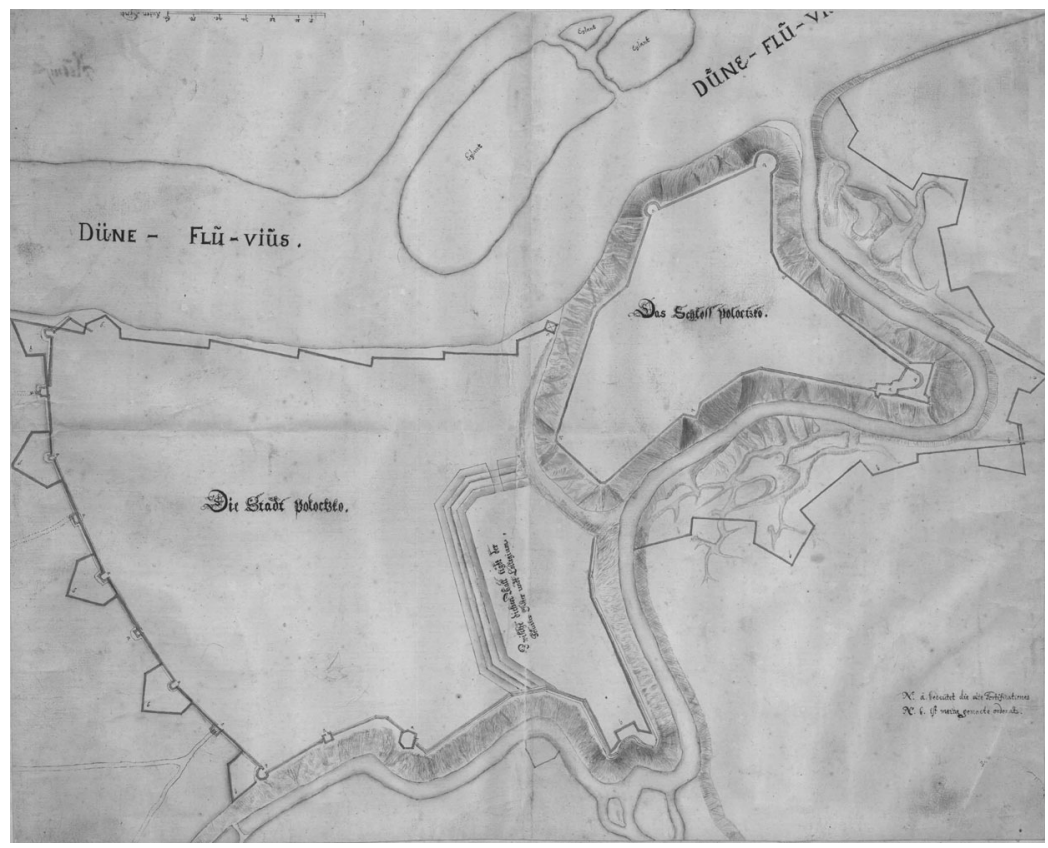

Il. 8. Plan rozbudowy Połocka z połowy XVII wieku (Kriegsarkivet (Stockholm), Utländska stads- och fästningsplaner, Polen, Polock 1)

już w latach 1670, 1673 użyto określenia „forteca Połocka”, w 1676 roku przypomniano jedynie o uzupełnieniu załogi, nie zaś o budowie fortyfikacji ${ }^{39}$.

Plan powstał prawdopodobnie w latach 1647-1654 albo 1667$1670^{40}$. Biorąc pod uwagę, że duża część dokumentacji kartograficznej trafiła w ręce Szwedów (i obecnie przechowywana jest w Kriegsarkivet $\mathrm{w}$ Sztokholmie) podczas tak zwanego potopu, bardziej prawdo-

39 Volumina legum, t. 5, wyd. J. Ohryzko, Petersburg 1860, s. 56, 93, 214.

40 Andrej Kotlarczuk uważa, że praca ta powstała w 1702 roku. А. Катлярчук, Шведы ў гісторыі і культуры беларусаў, Мінск 2007, s. 262. 
podobna jest pierwsza data ${ }^{41}$. Nie można jednak wykluczyć zdobycia planu podczas wielkiej wojny północnej ${ }^{42}$.

Plan ukazuje koncepcje znacznego wzmocnienia zamków i miasta przez stworzenie fortyfikacji bastionowych. Jest to praca skrupulatnie wykonana (dołączono podziałkę w prętach reńskich) w skali $1: 2700$, a jej rozmiary wynoszą $570 \times 456 \mathrm{~mm}^{43}$. Podkreślić należy, że kolorem czerwonym zaznaczono planowaną rozbudowę fortyfikacji, której zresztą nie zrealizowano. Zwracam uwagę, że w 1707 roku miasto Połock zostało ufortyfikowane w sposób zbliżony do projektu z XVII wieku. Skupiono się przede wszystkim na wzmocnieniu boku pomiędzy Połotą a Dźwiną za pomocą założeń bastionowych dodatkowo wzmocnionych redutami (zob. il. 7, 8) ${ }^{44}$. Natomiast nie został przeprowadzony śmiały plan wysunięcia założeń bastionowych

${ }^{41}$ Nie pozwala na dokładniejszą precyzję opis: „Zwische dießen Wall ligdt der Jesuiter Claster undt Collegium”. Kriegsarkivet (Stockholm), Utländska stads- och fästningsplaner, Polen, Polock 1. Klasztor i kolegium jezuickie w Połocku zostały założone już przez Stefana Batorego. Zob. Fundatio et dotatio Collegii Societatis Jesu in arce et civitate Polocensi a Serenissimo Rege Stephano, huius nominis primo feliciter institur. Datum Vilnae [...] Anno Domini 1582, w: Materialy do dziejów Akademii Połockiej i szkół od niej zależnych, wyd. I. G[iżycki], Kraków 1905, s. 44-46; А.А. Соловьёв, Полоцкий иезуитский коллегиум в ретроспективе (1581-1914): архитектурно-археологический очерк, Полоцк 2012, s. 16-32.

${ }^{42}$ K. Łopatecki, W. Walczak, Mapy i plany Rzeczypospolitej XVII w. znajdujace się $w$ Sztokholmie, t. 1, Warszawa 2011, s. 50, 52. Z szerszej perspektywy ujmuja temat: D. Matelski, Straty polskich dóbr kultury w wojnach ze Szwecja w XVII i XVIII wieku oraz próby ich restytucji, „Archeion” 106 (2003), s. 118-134; Z. Ciesielski, Grabieże dóbr kulturalnych $w$ Polsce przez Szwedów w XVII i początkach XVIII wieku, "Zapiski Historyczne” 68 (2003), 2-3, s. 97-108; J. Podralski, Wywóz dóbr materialnych $z$ Polski przez Szwedów podczas wojny w 1656 roku, „Przegląd Zachodniopomorski" 12 (1997), 1-2, s. 325-337.

43 U. Ehrensvärd, Cartographica Poloniae 1570-1930. Catalogue of Manuscript Sources in Swedish Collections to the History of Polish Territories, Warsaw-Stockholm 2008, s. 160. Ta najwybitniejsza specjalistka od dawnej kartografii zgromadzonej w zbiorach szwedzkich uznała ten plan za powstały w połowie XVII wieku.

44 Библиотека Российской Академии наук, Санкт-Петербург, Рукописный отдел, Собрание иностранных рукописей, $\mathrm{F}^{\circ} 266$, t. 4 , k. 48, rys. 52; Российский государственный военно-исторический архив, f. 846, op. 16, dz. 22367. 
przed rzekę Połotę, które stanowić powinny zewnętrzny pierścień obronny. Na planie częściowo zaznaczone są fortyfikacje zamku górnego z kilkoma umocnieniami, być może pamiętającymi czasy batoriańskie. Narysowano dwie basteje i częściowo przekształcony, wysunięty na południowym cyplu wzniesienia bastion (pierwotnie oflankowany dwoma bastejami anguł, zob. il. 8, 9) ${ }^{45}$. Do kształtu zamku strzeleckiego (dolnego) należy podejść z większą rezerwą, był on bowiem przebudowywany jeszcze za Stefana Batorego ${ }^{46}$. Na planie nie zachowały się baszty lub wieże, wydaje się jednak, że kształt wzgórza nie został przekształcony.

Zestawienie źródeł kartograficznych (il. 8, 9) wskazuje, że wyspa znajdowała się dokładnie na wysokości środkowego zamku. Sam zamek górny usytuowany był nad Dźwiną, co podkreślają również źródła pisane ${ }^{47}$. Rzuca się w oczy inny bieg rzeki Połoty - odmienny zarówno w stosunku do szesnastowiecznego rysunku, jak i sztychu. W połowie XVII wieku meandruje ona, zaś fortyfikacje obu zamków ściśle dopasowują się do jej biegu. Wydaje się jednak, że w przeszłości rzeka płynęła tak jak ukazuje to miedzioryt Pachołowieckiego-Cavalieriego. Na siedemnastowiecznym rysunku znajdują się bowiem starorzecza, wskazujące na odmienny bieg rzeki. Hipotezę tę potwierdza również opis zawarty u Heidensteina:

45 Autor przy tych obiektach zaznaczył literę „a”, którą w legendzie opisał jako „bedeutet die alte Fortificationes”. Kriegsarkivet (Stockholm), Utländska stads- och fästningsplaner, Polen, Polock 1.

46 R. Heidenstein, Dzieje Polski..., s. 326: „Król rozkazał Węgrom rozkopać zaraz i zasypać fossy i przekopy, dla szturmu porobione. Pokazał wyraźnie jak sobie życzy zburzoną część muru odbudować i zamek sam umocnić”. Por. Spisanie armaty Połockiej za króla Stefana, w: Sprawy wojenne króla Stefana Batorego. Dyjaryjusze, relacyje, listy i akta z lat 1576-1586, wyd. I. Polkowski, Kraków 1887, 175-177; M. Ferenc, Mikołaj Radziwiłt „Rudy” (ok. 1515-1584). Działalność polityczna i wojskowa, Kraków 2008, s. 584-585.

47 R. Heidenstein, Dzieje Polski..., s. 313: „zamek stoi na wyniosłej górze, na południe ma Dźwinę, na północ i wschód Połotę i miasteczko Zapołocie, a na zachód zamek Strzelców”. 


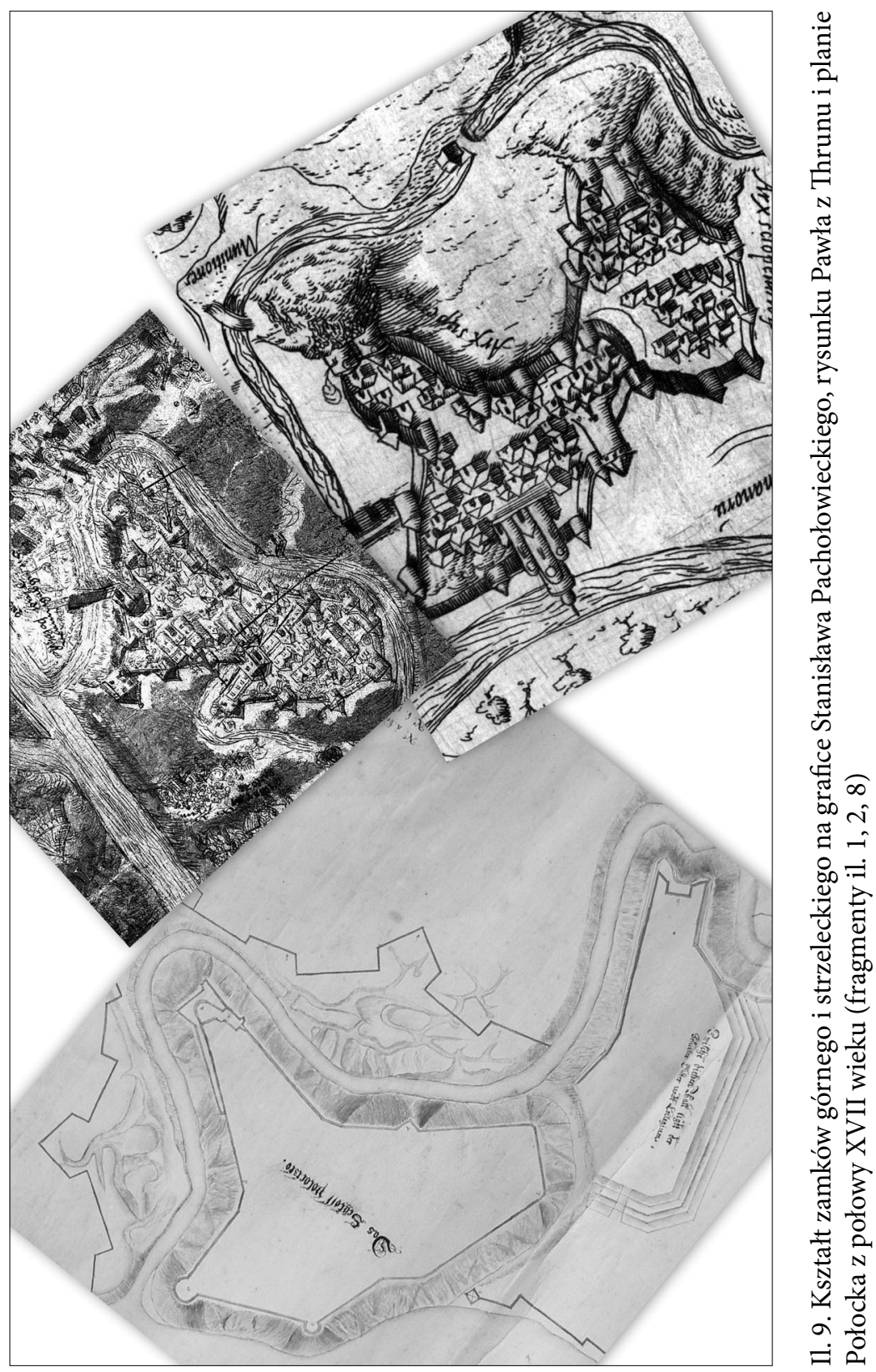


Połota płynąc prosto z północy skręca się pod Ostrogiem Strzeleckim nieco ku zachodowi [czyli wchodzi „nieco” w lukę pomiędzy zamkami - K.Ł.], a stąd zwracając się znowu ku północy obmywa stopy wzgórza [z wysuniętym angułem - K.Ł.], na którym wyższy zamek się wznosi, oddzielając go zarazem od miasta ${ }^{48}$.

Na podstawie przeprowadzonej analizy uważam, że bardziej wiarygodnym źródłem jest rycina wydana w 1580 roku niż rysunek Pawła $z$ Thurnu. Podstawowe elementy są zgodne z planem Połocka wymierzonym w połowie XVII stulecia (il. 9). A zatem odrzucić należy tezę prof. Stanisława Alexandrowicza, że rysunek Pachołowieckiego został znacznie zmodyfikowany przez sztycharzy ${ }^{49}$. Warto ponadto dodać, że od sztycharzy nie oczekiwano raczej twórczego wkładu $\mathrm{w}$ przygotowany materiał ikonograficzny wykonany przez dobrze opłacanych artystów ${ }^{50}$.

Porównanie grafiki z planem powstałym w XVII wieku wskazuje, że z punktu widzenia militarnego praca kartograficzna Stanisława Pachołowieckiego była bardzo dobra. Należy podkreślić, że pierwotny rysunek z sierpnia 1579 roku został wykonany bez wykorzystania przyrządów mierniczych. Wiele wskazuje, że plan sporządzono podczas objazdu fortyfikacji przez naczelne dowództwo 11 sierpnia $^{51}$. Stąd wynikają pewne jego mankamenty. Po pierwsze, rysunek i oparty na nim sztych nie został wyposażony podziałkę, bra-

48 R. Heidenstein, Pamiętniki wojny moskiewskiej..., s. 53.

49 S. Alexandrowicz, Kartografia Wielkiego Księstwa Litewskiego..., s. 177: „porównanie [...] wykazuje dowodnie, że ówcześni sztycharze, wykonujący swe prace na podstawie sporządzonych w polu rysunków, oddających rzeczywistą topografię i rozmieszczenie obiektów, wprowadzali niekiedy daleko idące zmiany obrazu, uzasadniające względami kompozycyjnymi”.

50 Jest to dobrze widoczne w twórczości Erika Dahlbergha. K. Łopatecki, Stan badań nad ocenq wiarygodności grafik autorstwa Erika Dahlbergha, w: Stan badań nad wielokulturowym dziedzictwem dawnej Rzeczypospolitej, t. 9, red. W. Walczak, K. Łopatecki, Białystok 2017, s. 199.

51 Plan fortyfikacji Połocka wykonano 11 sierpnia 1579 roku, kiedy Stefan Batory, Kasper Bekiesz i Jan Zamoyski objechali twierdzę, oceniając stan fortyfikacji i planując podjęcie działań oblężniczych. R. Heidenstein, Dzieje Polski..., s. 312- 
kuje nawet kierunków geograficznych (w rzeczywistości orientacja południowa). Ten ostatni fakt jest zdumiewający, trudno sobie bowiem wyobrazić, aby w armii nikt nie posiadał busoli albo kompa$\mathrm{su}^{52}$. Po drugie, mapa nie ma jednolitej skali. Stanisław Alexandrowicz ustalił, że skala wysztychowanego planu jest zmienna i wynosi od około $1: 18700$ do około $1: 24000^{53}$.

Jedynym poważnym błędem autora mapy jest przedstawienie zbyt szerokiego kąta powstałego pomiędzy brzegiem Dźwiny a odchodzącą od rzeki fortyfikacją zamku górnego. W konsekwencji kąty powstałe z przylegających do siebie zamków nie są oddane bardzo dokładnie, jednak zbliżone do sytuacji rzeczywistej i bez porównania lepiej przedstawione niż na rysunku. Oczywiście było to pokłosiem niestosowania narzędzi mierniczych i kartograficznych przez twórcę planu.

Pełną wartość dzieła Pachołowieckiego zrozumiemy, jeżeli w analogiczny sposób przeanalizujemy rysunek Pawła z Thurnu. Całe założenie fortyfikacyjne jest przedstawione niepoprawnie. Wynika to z przyjęcia błędnego założenia, że zamek górny nie był ulokowany nad Dźwiną. Tylko jedna masywna baszta na rysunku znajduje się w okolicach brzegu, zaś całość założenia fortyfikacyjnego odchodzi od linii rzeki. W konsekwencji mamy całkowicie zaburzone kąty tworzone przez linie umocnień zamku górnego. Jeszcze gorzej przedstawiony jest zamek strzelecki, którego kształt całkowicie odbiega od planu siedemnastowiecznego.

Odrębności występujące na ilustracji Pawła z Thurnu są bardzo duże w stosunku do grafiki. Tym bardziej niepokoją, że odmienna jest również orientacja obu przedstawień - na rysunku wschodnia, a na miedziorycie południowa. Bardzo duża jest na rysunku różnica pomiarów - według prof. Alexandrowicza skala u Pawła z Thurnu

314; idem, Pamiętniki wojny moskiewskiej..., s. 53, 55; M. Bielski, Kronika polska, wyd. J. Bielski, s. 761; А. Мартинелли, История взятия Полоцка..., s. 46.

${ }_{52}$ Kierunki geograficzne myli nawet Reinhold Heidenstein. Zob. S. Alexandrowicz, Nowe źródło..., s. 7-8.

${ }_{53}$ S. Alexandrowicz, Kartografia Wielkiego Księstwa Litewskiego..., s. 174. 
w poszczególnych częściach mapy wynosiła od $1: 8820$ do $1: 20400^{54}$. Różnice pomiędzy tymi danymi wynoszą aż $231 \%$, gdy odpowiednie zestawienie na podstawie pracy Pachołowieckiego daje wynik 128\%. Również sposoby opisania obu planów są odmienne. Rysunek nie ma tytułu, ale został zaopatrzony w epigramat:

Ereptum Moscis Stephano qui rege Polockum

Aspicis eximiis annuae principiis.

Sic prisci nobis redeunt post saecula reges,

Gens etiam redeat prisca Polona velim.

[Ty, co Połock zabrany przez króla Stefana Moskalom

Oglądasz tutaj, pochwalaj takie wspaniałe początki!

Tak nam oto wracają dawni po wiekach królowie:

Chciałbym, by także powrócił dawny naród Polaków.

przeł. Grzegorz Franczak]

Wszystkie te różnice wskazują, że Paweł z Thurnu wykorzystał inny rysunek przedstawiający oblężenie Połocka niż ten wykonany przez Pachołowieckiego. Pozorne podobieństwa wynikają oczywiście z wykonania planu identycznego obiektu. Sądzę, że wzorcem mógł być rysunek włoskiego inżyniera Piotra Frankusa. O tym, że mógł on wykonać taką pracę, informuje przywilej z 19 września 1579 roku wydany przez Stefana Batorego ${ }^{55}$. Z kolei w akcie nobilitacyjnym wystawionym dla Frankusa w 1582 roku geograf królewski był chwalony za wynajdowanie stosownych pozycji pod obozy oraz kierowanie pracami ziemnymi ${ }^{56}$. Wyższość rysunku nad miedziorytem niewątpliwie przejawia się natomiast w scenkach figuralnych

54 S. Alexandrowicz, Źródła kartograficzne do wyprawy połockiej..., s. 35.

${ }_{55}$ Diploma, quo cavetur, ne quisquam intra quinquennium expediiionis regiae ad Polockum imagines faciat praeter Petrum Francum Italum, w: Akta Metryki Koronnej co ważniejsze z czasów Stefana Batorego 1576-1586, wyd. A. Pawiński, Warszawa 1882, s. 66-67.

56 B. Paprocki, Herby rycerstwa polskiego, wyd. K.J. Turowski, Kraków 1858, s. 282; B. Kalicki, Nobilitacye króla Stefana na wyprawie moskiewskiej 1579-1581, w: Album lwowskie, wyd. H. Nowakowski, Lwów 1862, s. 97. 
przedstawiających przebieg oblężenia. Kwestia autorstwa pierwowzoru rysunku krakowskiego pozostaje nadal w sferze hipotez.

$\mathrm{Na}$ końcu wypada podzielić się wątpliwościami związanymi z niektórymi elementami wyeksponowanymi na rycinie. Sztych musiał zadziwiać osoby obeznane w możliwościach ówczesnych działań oblężniczych. Odbiorca nie odnajdował żadnej wskazówki, która tłumaczyłaby, jakim sposobem udało się zbudować i utrzymać w nienaruszonym stanie most, po którym przeprowadzono skuteczny atak na strome wzgórze w kierunku dwóch bastei. Na podstawie ryciny odnosiło się wrażenie, że Połock został najpierw oblężony przez wojska polsko-litewsko-węgiersko-niemieckie, a następnie zdobyty siłą w wyniku punktowego ataku piechoty. Napis na rycinie dodatkowo wzmacnia powyżej wyrażone przekonanie: „Obsessa XI Aug[usti], capta XXIX eius[dem] anno MDLXXIX" [Oblężona 11 sierpnia, wzięta 29 tegoż miesiąca roku 1579 - przeł. Grzegorz Franczak $]^{57}$.

Autor przedstawia dwie baterie węgierskie ulokowane naprzeciwko Zapołocia wraz z rozbudowanymi dziełami oblężniczymi, które w zasadzie doprowadzone zostały pod samą fosę (il. 10a). To oczywista mistyfikacja - z pewnością takich prac ziemnych nie wykonano. Było to niemożliwe $\mathrm{w}$ tak krótkim czasie. 11 sierpnia wojska dotarly pod Połock, a już następnego dnia miasto zostało spalone i zajęte. Takie rozwiązania inżynieryjne istniały, ale były wynikiem znacznego nakładu pracy i obejmowały w większości teren zdobytego Zapołocia, co zresztą prezentuje rysunek Pawła z Thurnu (il. 10b).

Od dawna historycy zwracają uwagę na błąd w dacie odnotowany na grafice prezentującej zdobycie Połocka ${ }^{58}$. Generalnie nie

57 G. Franczak, Atlas Księstwa Połockiego Stanisława Pachołowieckiego..., s. 68, inny fragment: „obsessa a Sereniss[imo] Poloniae rege Stephano XI Augusti et Moschis strenue defendentibus erepta XXIX eiusd[em] anno Domini MDLXXIX" (oblężony przez Najjaśniejszego Króla Polski Stefana 11 sierpnia i zdobyty mimo zaciętej obrony Moskwicinów 29 tegoż miesiąca, roku Pańskiego 1579), ibidem.

58 Wszelkie źródła pisane z epoki utożsamiają upadek twierdzy z 30 lub 31 sierpnia 1579 roku. Szerzej o kontrowersjach związanych z datą upadku Połocka zob. D. Kupisz, Połock 1579, Warszawa 2003, s. 146-153. 


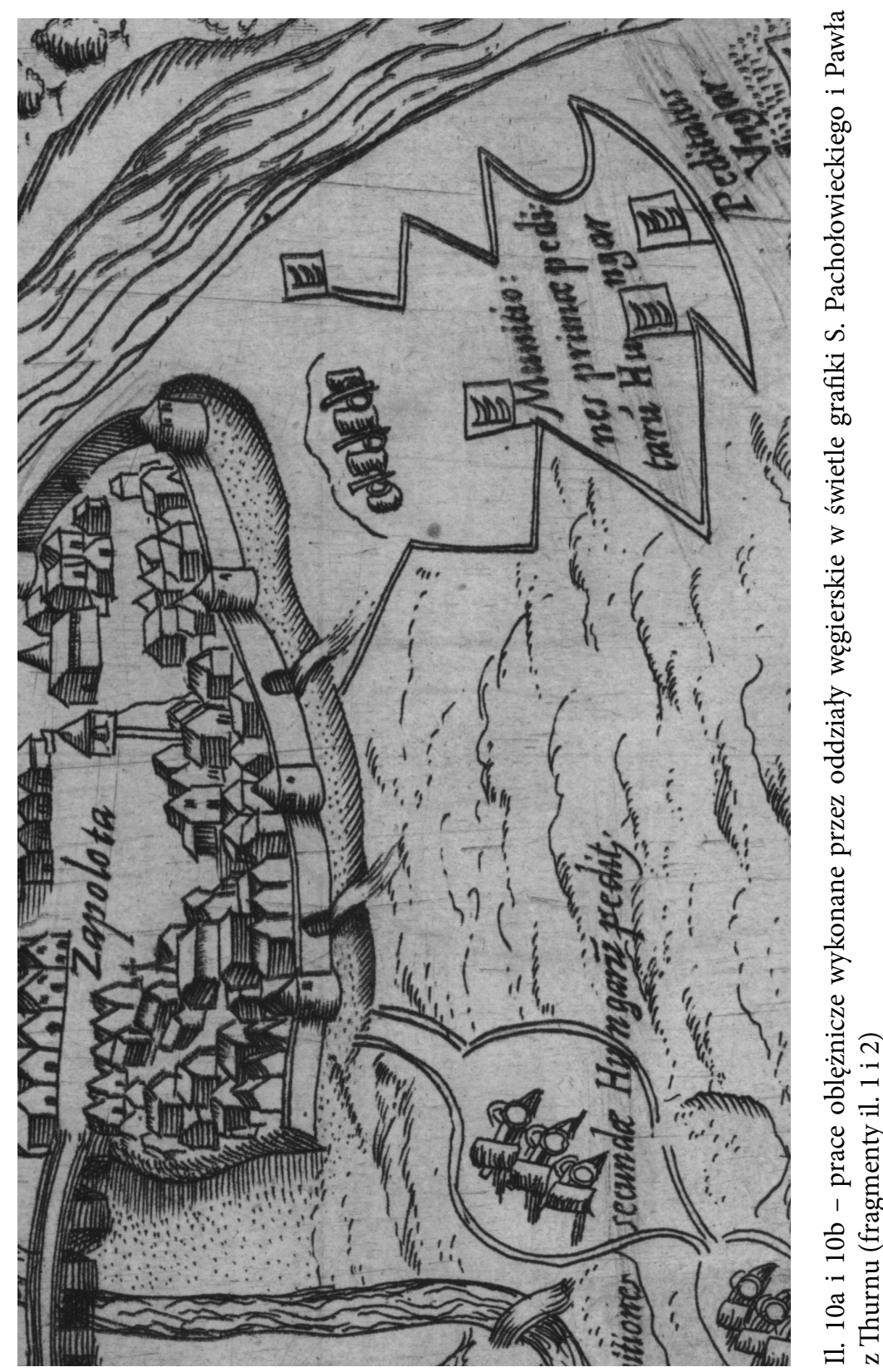




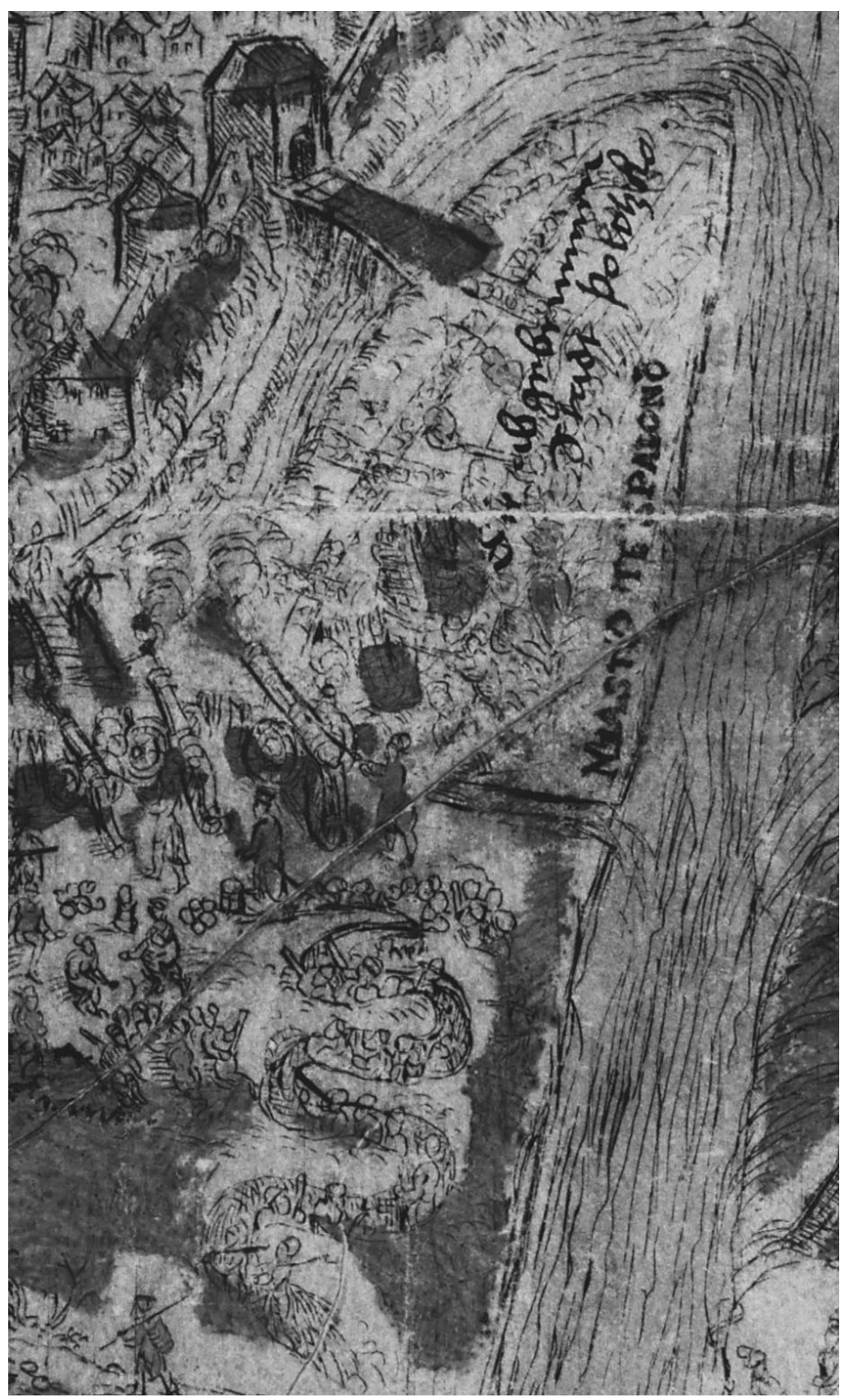


przejmowano się tym faktem, uważając, że mamy do czynienia ze zwykłą pomyłką, ewentualnie chęcią wyróżnienia daty szturmu. Czy rzeczywiście? Tę ocenę zmienia medal i donatywa dziesięciodukatowa upamiętniające triumf Stefana Batorego pod Połockiem ${ }^{59}$. Zostały one wybite w Gdańsku w 1582 roku w mennicy prowadzonej przez Gobeliuszy, o czym informuje stempel z herbem (pierścień z kamieniem - il. 11) ${ }^{60}$. Na tej dużej monecie o średnicy niemal $40 \mathrm{~mm}$ umieszczono stosunkowo rozbudowany napis. Na awersie znajduje się inskrypcja: STEPHANUS D[EI] G[RATIA] REX POL[ONIAE] MAG[NUS] DUX LIT[HUANIAE] RUSSI[AE] P[RUSSIAE], a przekaz propagandowy umieszczono na rewersie: DIES MENSIS ET ANNUS CAPTAE POLOCIAE BIS DENA AUGUSTI NONAQUE POLOCIA CAPTA EST LUCE DOLENT HOSTES CASTRA RAPIT STEPHANUS [Dzień miesiąca i rok zdobycia Połocka. Dwudziestego dziewiątego sierpnia Połock zdobyto za dnia. Wróg się smuci. Stefan pustoszy zamek] ${ }^{61}$.

Przy tak ważnych przedsięwzięciach jak przygotowanie sztychu albo zaprojektowanie medalu trudno uwierzyć w pomyłkę. O ile jednak w pojedynczym przypadku istnieje pewna niepewność w tej materii, o tyle dwukrotne użycie tej samej daty taką pomyłkę wyklucza. Dodam, że oba dzieła skierowane były przede wszystkim do odbiorcy

\footnotetext{
59 M. Ferenc, Mikołaj Radziwitt „Rudy”..., s. 585.

60 M. Gumowski, Bracia Gobeliusze, „Zapiski Towarzystwa Naukowego w Toruniu" 14 (1948), 1-4, s. 66, 68.

${ }^{61}$ F. Bentkowski, Spis medalów polskich lub z dziejami krainy polskiéj stycznych, Warszawa 1830, s. 14, poz. 49; J. Dutkowski, A. Suchanek, Corpus nummorum Gedanensis. Katalog-cennik monet, medali i żetonów gdańskich i z Gdańskiem związanych, Gdańsk 2000, s. 221; J. Lelewel, O monecie polskiej, przeł. E. Januszkiewicz, Poznań 1862, s. 29-30; J. Lelewel, Polska, dzieje i rzeczy jej, t. 5, Poznań 1863, s. 282; E. Raczyński, Gabinet medalów polskich oraz tych które się dziejów Polski tycza począwszy od najdawniejszych aż do końca panowania Jana III (1513-1698), t. 1, Wrocław 1838, s. 210-211, nr 53; J.F. Kluczycki, Pamiątki polskie w Wiedniu i jego okolicach: jakoteż inne wiadomości, Kraków 1835, s. 143, poz. 16.
} 

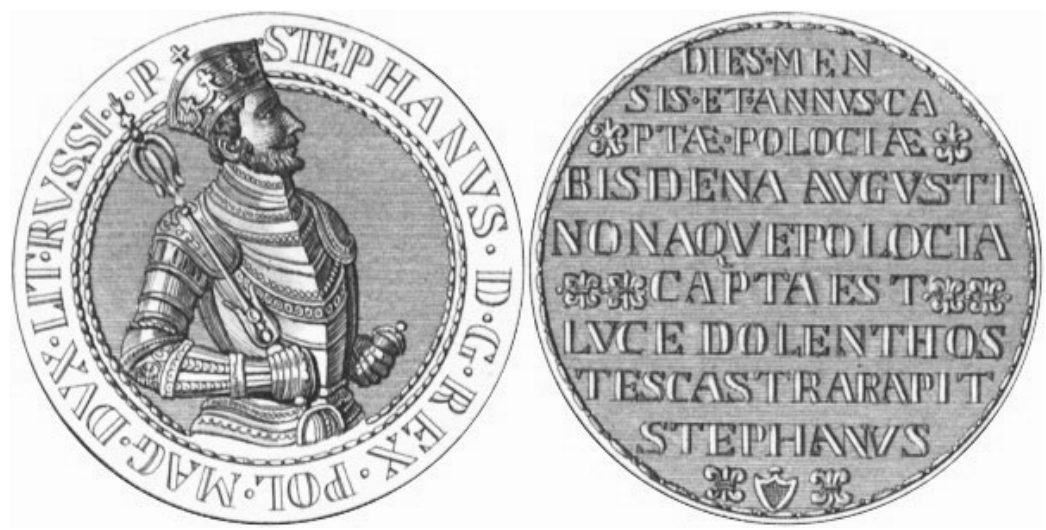

Il. 11. Medal Stefana Batorego upamiętniający zdobycie Połocka $\mathrm{z}$ datą dzienną 29 sierpnia 1579 roku (http://gabinetmedalow.m4n.pl/data.php? data=53, dostęp: 24.09 .2017 )

europejskiego ${ }^{62}$. Tymczasem w źródłach z epoki, jeśli są jakieś rozbieżności dotyczące daty upadku twierdzy, to odnoszą się do dat 30 lub 31 sierpnia. W związku z tym inne źródła nie tłumaczą, skąd data 29 sierpnia. Moim zdaniem dla współczesnych dzień ten był oczywistym nawiązaniem do wojny starodubskiej. W 1535 roku, 29 sierpnia, armia dowodzona przez hetmana wielkiego koronnego Jana Tarnowskiego i hetmana wielkiego litewskiego Jerzego Radziwiłła zdobyła po miesięcznym oblężeniu twierdzę Starodub. Około 1000-1400 wziętych do niewoli jeńców moskiewskich Tarnowski kazał ściąćc ${ }^{63}$. Sugero-

62 Zob. J.D. Köhlers, Im Jahr 1750. wöchentlich heraus gegebener Historischer Münz-Belustigung, Bd. 22, Nürnberg 1750, s. 409-416; H. Lübeck, Sammlung PreuBischer und Polnischer Medaillen wie auch Thaler welche auf allerhand Begebenheiten geschlagen und von Seel. Herrn Heinrich Lübeck Höchstemeritierten Mitglied des Rahts Collegii der Königl. Stadt Königsberg in Preussen colligiret, Königsberg-Leipzig 1737, s. 32.

63 М.М. Кром, Стародубская война 1534-1537. Из истории русско-литовских отношениц, Москва 2008, s. 74-83; W. Dworzaczek, Hetman Jan Tarnowski. Z dziejów możnowładztwa małopolskiego, Warszawa 1985, s. 75-77. 
wanie odbiorcy zdobycia twierdzy siłą miało upodobnić oba wydarzenia. Po pierwsze, stanowi to nawiązanie do największego zwycięstwa litewsko-polskiego nad Moskwą w pierwszej połowie XVI wieku. Po drugie, ukazane zostaje miłosierdzie Stefana Batorego, który pozwala przegranym opuścić zdobytą twierdzę i wrócić do domu. Wskazać trzeba, że w świadomości mieszkańców państwa moskiewskiego utrzymywała się pamięć o tym krwawym wydarzeniu i wielokrotnie w latach 60. XVI wieku przypominano o nim stronie litewsko-polskiej ${ }^{64}$. Oba wydarzenia łączy fakt przedstawienia ich na grafice. Triumf z 1535 roku upamiętniono drzeworytem w Kronice Marcina Bielskiego z 1564 roku, wykorzystanym powtórnie, jak pisałem wyżej, w opisaniu Sarmacji Aleksandra Gwagnina jako ilustracja oblężenia Połocka.

\section{Podsumowanie}

1. Przeprowadzona analiza wskazuje, że drzeworytu Georga Macka młodszego nie można traktować jako wiarygodnego źródła kartograficznego, a jedynie jako wytwór imaginacji autora. Rycina została wykonana na podstawie informacji pisanych i nie wydaje się, aby autor znał jakiekolwiek plany wykonane pod Połockim. Przykład drzeworytu prezentującego oblężenie twierdzy Starodub, który następnie został w pracy Gwagnina powtórzony jako zdobycie Połocka, dowodzi, że każdorazowo należy przeprowadzić krytykę źródła (il. 3, 4).

2. Wbrew dotychczasowym ocenom badaczy należy przyjąć, że plan Stanisława Pachołowieckiego i rysunek Pawła z Thurnu zasadniczo różnią się z punktu widzenia prawidłowego

64 Сборник Императорского Русского исторического общества, вып. 71: Памятники дипломатических сночений Московского государства с Польско-Литовским государством. Ч.3. (годы с 1560 по 1570), под наблюдением Г.Ф. Карпова, Санкт-Петербург 1892, s. 128, 293. 
wykonania dzieła kartograficznego. Do najważniejszych różnic zaliczam odmienne zaznaczenie wyspy na Dźwinie, lokalizacji zamku górnego, obozu królewskiego, biegu rzeki Połoty na wysokości obu zamków (il. 6), orientacji, różna jest ponadto skala. Zachowany rysunek Pawła z Thurnu nie wywodzi się $\mathrm{z}$ tego samego archetypu co sztych. Być może pierwowzorem było dzieło inżyniera włoskiego Piotra Frankusa. Nie wydaje się zatem uprawnione posługiwanie się przy opisie rysunku podwójnym autorstwem: Pachołowiecki-Zumthorn.

3. Najbardziej precyzyjnym i wiarygodnym planem Połocka z 1579 roku jest plan Stanisława Pachołowieckiego (il. 1). Zarys fortyfikacji przedstawiono w sposób bardzo dobry. Jest on zasadniczo zgodny z treścią planu Połocka powstałego w połowie XVII wieku (il. 8). Jeśli chodzi o ukazanie elementów topograficznych, w szczególności biegu Połoty oraz lokalizacji wyspy na Dźwinie, a także uwzględnienie „rowu” czy też „jeziora” położonego na wschód od zamku strzeleckiego, plan Pachołowieckiego jest zdecydowanie lepszy od rysunku Pawła z Thurnu. Jednoznacznie odrzucam hipotezę postawioną przez Stanisława Alexandrowicza o dużej ingerencji sztycharzy w ostateczny kształt ryciny.

4. W artykule zaprezentowano nieznany szerzej plan rozbudowy Połocka przechowywany w Riksarkivet w Sztokholmie (il. 8). Ustalono, że powstał on prawdopodobnie w latach 1647-1654 jako konsekwencja zniszczenia zamków przez pożar. Na planie ukazano dotychczasowe fortyfikacje, kolorem czerwonym naniesiono planowane założenia bastionowe. Inżynier wojskowy w śmiałej koncepcji zrezygnował z naturalnej obrony, jaką dawała rzeka Połota i planował wybudować fortyfikacje bastionowe wysunięte przed rzeczkę. Pierścień ten dawałby pierwszą linię obrony o foremnym kształcie i zapewniał dobrą synchronizację obronną z zamkiem strzeleckim. Porównanie tego planu z mapą powstałą w 1707 roku wskazuje, że koncepcja ta nie została zrealizowana (il. 7).

5. Rezultaty badań przedstawione w artykule potwierdzają skuteczność zaproponowanej przez Stanisława Alexandrowicza metody 
porównawczej obiektów kartograficznych obejmujących tożsamy obszar, a pochodzących z różnych czasów. Działania takie pozwalają ocenić wiarygodność źródeł wcześniejszych, ale również wnoszą nowe przydatne informacje. Należy jednak pamiętać o możliwych znacznych przekształceniach hydrogeologicznych, nie wspominając o zmianach urbanistycznych i fortyfikacyjnych. Dlatego należy dążyć do odszukania możliwie najbliższego chronologicznie materiału kartograficznego.

6. Rycina Stanisława Pachołowieckiego Obsidio et expugnatio munitiss[imae] arcis Polocensis per Sereniss [imum] Stephanum Poloniae regem w sposób niezgodny ze znaną nam faktografią przedstawia działania oblężnicze prowadzone przy Zapołociu (il. 10). Ponadto autor manipuluje datą zdobycia Połocka. Podanie tu dnia 29 sierpnia nie może być przypadkowym błędem, gdyż identyczna data znajduje się również na medalu wybitym w Gdańsku w 1582 roku (il. 11). Przyjęcie 29 sierpnia 1579 roku za datę upadku Połocka pozwoliło na utożsamienie dwóch podobnych wydarzeń: zdobycia Połocka i Starodubu w 1535 roku. Oba wydarzenia zostały upamiętnione w ówczesnej grafice - pierwsze drzeworytem, drugie - sztychem miedziorytniczym. 


\section{Bibliografia}

\section{Archiwalia}

Библиотека Российской Академии наук, Санкт-Петербург, Рукописный отдел, Собрание иностранных рукописей, $\mathrm{F}^{\circ}$ 266, т. 4, k. 48, rys. 52.

Российский государственный военно-исторический архив, f. 846, ор. 16, dz. 22367.

Biblioteca Comunale Augusta, Perugia, sygn. St. Serie I n. 63.

Bibliothèque Nationale de France, Coll. Lallemand de Betz, sygn. VX-48-FOL, fol. 202-203, n. 7455.

British Library, sygn. Maps *33825, C.7.e.4.(54.).

Kriegsarkivet (Stockholm), Utländska stads- och fästningsplaner, Polen, Polock 1. Muzeum Wojska Polskiego w Warszawie, nr inw. 16594 A*$^{\star}, 16595 \mathrm{~A}^{\star}, 16596 \mathrm{~A}^{\star}$, $16597 \mathrm{~A}^{*}$.

Royal Collection Trust, sygn. RCIN 721074.

Staatsarchiv Dresden, sygn. R. Schrank VII, Fach 90, nr 17a.

Zamek Królewski w Warszawie - Muzeum, Kolekcja dr. Tomasza Niewodniczańskiego, sygn. TN 2826 (dep. Deutsch-Polnische Stiftung Kulturpflege und Denkmalschutz).

\section{Źródła drukowane}

Археографический сборник документов, относящихся к истории Северо-Западной Руси, т. 1, Вильно 1867.

Мартинелли А., История взятия Полочка польским королем Стебаном Баторием в 1579 году, подготовка текста и перевод И.В. Дубровского, w: Русский Сборник. Исследования по истории России, т. 21, ред. О.Р. Айрапетов et al., Москва 2017, s. 7-100.

Сборник Императорского Русского исторического общества, вып. 71: Памятники дипломатических сночений Московского государства с Польско-Литовским государством. Ч.3. (годы с 1560 по 1570), под наблюдением Г.Ф. Карпова, Санкт-Петербург 1892.

Akta Metryki Koronnej co ważniejsze z czasów Stefana Batorego 1576-1586, wyd. A. Pawiński, Warszawa 1882.

Bielski M., Kronika polska, wyd. J. Bielski, Kraków: Jakub Siebeneicher, 1597.

Bielski M., Kronika to jest, historyja świata [...], Kraków: Mateusz Siebeneicher, 1564.

Gwagnin A., Kronika Sarmacyjej Europskiej, Kraków: Mikołaj Lob, 1611. 
Heidenstein R., De bello Moscovitico Commentariorum, lib. sex, Kraków: Drukarnia Łazarzowa, 1584.

Heidenstein R., Dzieje Polski od śmierci Zygmunta Augusta do roku 1594. Ksiąg XII, t. 1, przeł. M. Gliszczyński, Petersburg 1857.

Heidenstein R., Pamiętniki wojny moskiewskiej w 6 księgach, przeł. i wyd. J. Czubek, Lwów 1894.

Köhlers D., Im Jahr 1750. wöchentlich heraus gegebener Historischer Münz-Belustigung, Bd. 22, Nürnberg 1750.

Lübeck H., Sammlung Preußischer und Polnischer Medaillen wie auch Thaler welche auf allerhand Begebenheiten geschlagen und von Seel. Herrn Heinrich Lübeck Höchstemeritierten Mitglied des Rahts Collegii der Königl. Stadt Königsberg in Preussen colligiret, Königsberg-Leipzig 1737.

Materiały do dziejów Akademii Połockiej i szkół od niej zależnych, wyd. I. G[iżycki], Kraków 1905.

Paprocki B., Herby rycerstwa polskiego, wyd. K.J. Turowski, Kraków 1858.

Volumina legum, t. 2-5, wyd. J. Ohryzko, Petersburg 1859-1860.

Warhaffte Contrafactur vnd gewisse Zeitung, welcher massen die Königliche Wirden in Poln, die Stat vnnd daß Schloß Polotzko in Littawen gelegen, sampt andern Heusern, die der Moscowiter vor der zeyt der Korn vnbillich abgedrungen, widerumben belegert vnd eingenommen. Auch was sich in solchem Zug verloffen hat, Nürnberg: Georg Mack, [1579].

\section{Opracowania}

Арлоў У., Герасімовіч 3., Ілюстраваная гісторья: краіна Беларусь, Bratislava 2003.

Белы А., Plan von Polotzko anno 1707, „Спадчына” 10 (1998), 4, s. 12-15.

Белы А., Полацк у нямецкіх “Лятучых лістках” XVI cm. Інфляникая вайна на старонках першых еурапейскіх газет, „Спадчына” 9 (1997), 6, s. 213-219.

Дук Д.В., Исследование оборонительных сооружений. Материаль городской застройки, w: Полоик, ред. О.Н. Левко, Минск 2012, s. 309-324.

Дук Д., Матэрыяль да геральдычнай карты месияазнаходжання двароў полацкай шляхты XVI-XVII cm., „Герольд Litherland” 2 (2002), 3-4, s. 84-89.

Дук Д.У., Полацк і палачане (IX-XVIII cmcm.), Наваполацк 2010.

Катлярчук А., Шведы ў гісторы і культуры беларусаў, Мінск 2007.

Кром М.М., Стародубская война 1534-1537. Из истории русско-литовских отношений, Москва 2008.

Платонов Р.М., Платонов М.А., Давидович А.С., Градостроительство Полоцка в XIV-XVIII века, „Вестник Полоцкого государственного университета. Cер. F, Прикладные науки. Строительство. Прикладные науки: научно-теоретический журнал” 12 (2009), s. 7-13. 
Соловьёв А.А., Полоцкий иезуитский коллегиум в ретроспективе (1581-1914): архитектурно-археологический очерк, Полоцк 2012.

Филиппенко Я.Д., Исторический и композииионный анализ градообразующей роли центральной площзади Полоцка XVI-XIX веков, „Вестник Полоцкого государственного университета. Серия F, Строительство. Прикладные науки: научно-теоретический журнал” 6 (2009), s. 15-20.

Филюшкин А.И., Завоевание Стебаном Баторием полоцка в 1579 г. в европейс- ком нарративе, „Вестник Санкт-Петербургского университета. Серия 2. История” 1 (2014), s. 5-9.

Цялежнікаў У.I., Латушкін А.M., Умацаванні 2-й паловы XVI cm. паміж Верхнім i Ніжнім замкамі ц̆ Полацку, „Пытанні мастацтвазнаўства, этналогіi і фалькларыстыкі” 17 (2014), s. 58-66.

Чантурия Ю.В., Градостроительное искусство Беларуси второй половинь XVI - первой половины ХІХ в., Минск 2005.

Штыхов Г.В., Тарасов С.В., Дук Д.В., Историография и источники, w: Полочк, ред. О.Н. Левко, Минск 2012, s. 13-35.

Alexandrowicz S., Dziedzictwo kartografii wojskowej ziem Wielkiego Księstwa Litewskiego. Jej funkcje źródłowe i praktyczne na tle kartografii krajów Europy Wschodniej XVI i XVII wieku, w: Środowisko kulturotwórcze i kontakty kulturalne na tle Wielkiego Księstwa Litewskiego od XV do XIX wieku, red. W. Augustyniak, Warszawa 2009, s. 191-204.

Alexandrowicz S., Kartografia Wielkiego Księstwa Litewskiego od XV do połowy XVIII wieku, Warszawa 2012.

Alexandrowicz S., Kartografia wojskowa Wielkiego Księstwa Litewskiego do połowy XVII wieku, w: Kartografia wojskowa krajów strefy bałtyckiej XVI-XX w. Materiały konferencji naukowej, Toruń, 20-22 października 1994 r., red. S. Alexandrowicz, Z. Karpus, W. Rezmer, Toruń 1996, s. 11-22.

Alexandrowicz S., Nowe źródło ikonograficzne do oblężenia Połocka w 1579 r., „Kwartalnik Historii Kultury Materialnej” 19 (1971), nr 1, s. 3-29.

Alexandrowicz S., Źródła kartograficzne do wyprawy połockiej Stefana Batorego roku 1579, w: Od armii komputowej do narodowej (XVI-XX w.), red. Z. Karpus, W. Rezmer, Toruń 1998, s. 17-43.

Bentkowski F., Spis medalów polskich lub z dziejami krainy polskiéj stycznych, Warszawa 1830.

Bobiatyński K., Od Smoleńska do Wilna. Wojna Rzeczypospolitej z Moskwa 16541655, Zabrze 2004.

Bönisch F., Brichzin H., Schillinger K., Stams W., Kursächsische Kartographie bis zum Dreissigjährigen Krieg, Bd. 1: Die Anfänge des Kartenwesens Gebundene Ausgabe, Berlin 1990.

Chojecka E., Drzeworyty Kroniki Joachima Bielskiego i zaginione gobeliny Anny Jagiellonki. Ze studiów nad związkami artystycznymi Krakowa i Brzegu w XVI wieku, „Rocznik Sztuki Śląskiej” 7 (1970), s. 37-73.

Chrzanowski T., Działalność artystyczna Tomasza Tretera, Warszawa 1984. 
Ciesielski Z., Grabieże dóbr kulturalnych w Polsce przez Szwedów w XVII i początkach XVIII wieku, „Zapiski Historyczne” 68 (2003), 2-3, s. 97-108.

Dworzaczek W., Hetman Jan Tarnowski. Z dziejów możnowładztwa małopolskiego, Warszawa 1985.

Dutkowski J., Suchanek A., Corpus nummorum Gedanensis. Katalog-cennik monet, medali i żetonów gdańskich i z Gdańskiem związanych, Gdańsk 2000.

Dybaś B., Fortece Rzeczypospolitej. Studium $z$ dziejów budowy fortyfikacji stałych w państwie polsko-litewskim w XVII wieku, Torun 1998.

Ehrensvärd U., Cartographica Poloniae 1570-1930. Catalogue of Manuscript Sources in Swedish Collections to the History of Polish Territories, Warsaw-Stockholm 2008.

Ferenc M., Mikołaj Radziwiłł „Rudy” (ok. 1515-1584). Działalność polityczna i wojskowa, Kraków 2008.

Franczak G., Atlas Księstwa Połockiego Stanisława Pachołowieckiego z 1580 roku transkrypcja i przekład, „Terminus” 19 (2017), z. 1 (42), s. 61-74.

Gębarowicz M., Początki malarstwa historycznego w Polsce, Wrocław 1981.

Gumowski M., Bracia Gobeliusze, „Zapiski Towarzystwa Naukowego w Toruniu” 14 (1948), 1-4, s. 57-78.

Kalicki B., Nobilitacye króla Stefana na wyprawie moskiewskiej 1579-1581, w: Album lwowskie, wyd. H. Nowakowski, Lwów 1862, s. 69-98.

Kluczycki J.F., Pamiątki polskie w Wiedniu i jego okolicach: jakoteż inne wiadomości, Kraków 1835.

Kozica K., Charakterystyka prac kartograficznych Stanisława Pachołowieckiego (1580), „Terminus” 19 (2017), z. 1 (42), s. 37-59.

Kupisz D., Połock 1579, Warszawa 2003.

Lelewel J., O monecie polskiej, przeł. E. Januszkiewicz, Poznań 1862.

Lelewel J., Polska, dzieje i rzeczy jej, t. 5, Poznań 1863.

Łopatecki K., Organizacja, prawo i dyscyplina w polskim i litewskim pospolitym ruszeniu (do połowy XVII wieku), Białystok 2013.

Łopatecki K., Stan badań nad ocena wiarygodności grafik autorstwa Erika Dahlbergha, w: Stan badan nad wielokulturowym dziedzictwem dawnej Rzeczypospolitej, t. 9, red. W. Walczak, K. Łopatecki, Białystok 2017, s. 183-203.

Łopatecki K., Walczak W., Mapy i plany Rzeczypospolitej XVII w. znajdujace sie w Sztokholmie, t. 1, Warszawa 2011.

Matelski D., Straty polskich dóbr kultury w wojnach ze Szwecją w XVII i XVIII wieku oraz próby ich restytucji, „Archeion” 106 (2003), s. 118-138.

Morka M., [recenzja książki:] T. Jakimowicz, Temat historyczny w sztuce ostatnich Jagiellonów, „Biuletyn Historii Sztuki” 49 (1987), 3-4, s. 352-358.

Niedźwiedź J., Atlas Księstwa Połockiego Stanisława Pachołowieckiego (1580): propaganda, genologia i tworzenie wiedzy geograficzne, „Terminus” 19 (2017), z. 1 (42), s. 127-155. 
Niedźwiedź J., Polska szesnastowieczna propaganda wojenna $w$ działaniu: przypadek Atlasu Księstwa Połockiego (1580), „Terminus” 19 (2017), z. 3 (44), s. 477-510.

Pirożyński J., $Z$ dziejów obiegu informacji w Europie XVI wieku. Nowiny $z$ Polski w kolekcji Jana Jakuba Wicka w Zurychu z lat 1560-1587, Kraków 1995 (Zeszyty Naukowe Uniwersytetu Jagiellońskiego. Prace Historyczne 115).

Podralski J., Wywóz dóbr materialnych z Polski przez Szwedów podczas wojny w 1656 roku, „Przegląd Zachodniopomorski” 12 (1997), 1-2, s. 325-337.

Rastawiecki E., Słownik malarzów polskich, tudzież obcych $w$ Polsce osiadlych lub czasowo w niej przebywajacych, t. 2, Warszawa 1851.

Rohrschneider Ch, Czumturn (Czum Thurn; Czumstur; Czumthorn; Tomtorn; Tomturn), Pawet (Paul), w: Allgemeines Künstlerlexikon. Die bildenden Künstler aller Zeiten und Völker, Bd. 23, München 1999, s. 319.

Śnieżko D., Swojskie i obce w kronice uniwersalnej (przykład Marcina Bielskiego), „Teksty Drugie. Teoria literatury, krytyka, interpretacja” (2003), nr 1, s. 23-40.

Weller E., Die ersten deutschen Zeitungen mit einer Bibliographie (1505-1599), Hildesheim-Zürich-New York 1994.

Wisner H., Wojsko litewskie 1 połowy XVII wieku. Cz. II, „Studia i Materiały do Historii Wojskowości” 20 (1976), s. 5-26.

Zawadzki K., Akcja prasowa Stefana Batorego w czasie wypraw moskiewskich 15791581, w: Dzieje polskiej kartografii wojskowej i myśli strategicznej. Materiaty $z$ konferencji, oprac. B. Krassowski, J. Madej, Warszawa 1982, s. 119-125. 